\title{
Early Cytokine-Induced Transient NOX2 Activity Is ER Stress-Dependent and Impacts $\beta$-Cell Function and Survival
}

\author{
Eloisa A. Vilas-Boas ${ }^{1,2} \oplus$, Christopher Carlein ${ }^{1}$, Lisa Nalbach ${ }^{3}$, Davidson C. Almeida ${ }^{4}\left(\mathbb{D}\right.$, Emmanuel Ampofo ${ }^{3} \oplus$, \\ Angelo R. Carpinelli ${ }^{2}\left(\mathbb{D}\right.$, Leticia P. Roma ${ }^{1, *(1)}$ and Fernanda Ortis ${ }^{4, *}$ \\ 1 Center for Human and Molecular Biology (ZHMB), Department of Biophysics, Saarland University, \\ 66424 Homburg, Germany; elovilasboas@usp.br (E.A.V.-B.); christopher.carlein@uks.eu (C.C.) \\ 2 Department of Physiology and Biophysics, Institute of Biomedical Sciences, University of São Paulo (USP), \\ São Paulo 05508-000, Brazil; angelo@icb.usp.br \\ 3 Institute for Clinical and Experimental Surgery, Saarland University, 66424 Homburg, Germany; \\ lisa-nal@web.de (L.N.); emmanuel.ampofo@uks.eu (E.A.) \\ 4 Department of Cell and Developmental Biology, Institute of Biomedical Sciences, \\ University of São Paulo (USP), São Paulo 05508-000, Brazil; davidson.almeida@usp.br \\ * Correspondence: leticia.prates-roma@uks.eu (L.P.R.); fortis@usp.br (F.O.); Tel.: +06841-16-16240 (L.P.R.); \\ +55-(11)-3091-0923 (F.O.); Fax: +06841-16-16302 (L.P.R.)
}

\section{check for} updates

Citation: Vilas-Boas, E.A.; Carlein, C.; Nalbach, L.; Almeida, D.C.; Ampofo, E.; Carpinelli, A.R.; Roma, L.P.; Ortis, F. Early Cytokine-Induced Transient NOX2 Activity Is ER Stress-Dependent and Impacts $\beta$-Cell Function and Survival. Antioxidants 2021, 10, 1305. https://doi.org/ 10.3390/antiox10081305

Academic Editor: Mikko O. Laukkanen

Received: 18 July 2021

Accepted: 15 August 2021

Published: 18 August 2021

Publisher's Note: MDPI stays neutral with regard to jurisdictional claims in published maps and institutional affiliations.

Copyright: (c) 2021 by the authors. Licensee MDPI, Basel, Switzerland. This article is an open access article distributed under the terms and conditions of the Creative Commons Attribution (CC BY) license (https:/ / creativecommons.org/licenses/by/ $4.0 /)$.

\begin{abstract}
In type 1 diabetes (T1D) development, proinflammatory cytokines (PIC) released by immune cells lead to increased reactive oxygen species (ROS) production in $\beta$-cells. Nonetheless, the temporality of the events triggered and the role of different ROS sources remain unclear. Isolated islets from C57BL/6J wild-type (WT), NOX1 KO and NOX2 KO mice were exposed to a PIC combination. We show that cytokines increase $\mathrm{O}_{2}{ }^{\bullet-}$ production after $2 \mathrm{~h}$ in WT and NOX1 KO but not in NOX2 KO islets. Using transgenic mice constitutively expressing a genetically encoded compartment specific $\mathrm{H}_{2} \mathrm{O}_{2}$ sensor, we show, for the first time, a transient increase of cytosolic/nuclear $\mathrm{H}_{2} \mathrm{O}_{2}$ in islet cells between 4 and $5 \mathrm{~h}$ during cytokine exposure. The $\mathrm{H}_{2} \mathrm{O}_{2}$ increase coincides with the intracellular $\mathrm{NAD}(\mathrm{P}) \mathrm{H}$ decrease and is absent in NOX2 KO islets. NOX2 KO confers better glucose tolerance and protects against cytokine-induced islet secretory dysfunction and death. However, NOX2 absence does not counteract the cytokine effects in $\mathrm{ER} \mathrm{Ca}^{2+}$ depletion, Store-Operated Calcium Entry (SOCE) increase and ER stress. Instead, the activation of ER stress precedes $\mathrm{H}_{2} \mathrm{O}_{2}$ production. As early NOX2-driven ROS production impacts $\beta$-cells' function and survival during insulitis, NOX2 might be a potential target for designing therapies against early $\beta$-cell dysfunction in the context of T1D onset.
\end{abstract}

Keywords: $\beta$-cell; ER stress; hydrogen peroxide; insulitis; NADPH oxidase; oxidative stress; proinflammatory cytokines

\section{Introduction}

Type 1 diabetes mellitus (T1D) is a multifactorial disease, in which environmental factors trigger a specific and persistent autoimmune response against pancreatic $\beta$-cells in individuals with a genetic predisposition [1]. Islets are invaded by macrophages and T lymphocytes, leading to an inflammatory response, known as insulitis, with a massive destruction of $\beta$-cells [2,3]. During insulitis, several proinflammatory cytokines, mainly interleukin (IL)- $1 \beta$, tumor necrosis factor (TNF) and interferon (INF)- $\gamma$, are released by the immune cells. The main intracellular mechanisms triggered in $\beta$-cells include: (i) the activation of inducible nitric oxide synthase (iNOS) with nitric oxide (NO) production, (ii) calcium $\left(\mathrm{Ca}^{2+}\right)$ depletion in the endoplasmic reticulum (ER) and ER stress induction, (iii) excessive generation of reactive oxygen species (ROS) and consequent oxidative stress and (iv) alteration of the mitochondrial membrane potential and activation of caspases [2-4]. All these mechanisms contribute to the deleterious effects on insulin biosynthesis and secretion and culminate in apoptosis. 
The exposure of pancreatic islets and $\beta$-cell lines to proinflammatory cytokines, alone or in combination, leads to increased ROS production [5-7]. Additionally, pancreatic $\beta$ cells are believed to be highly susceptible to oxidative damage, due to a low expression of classical antioxidant enzymes [8]. However, the specific role of different sources of ROS and the time-based dynamics of ROS production in pancreatic islets during exposure to proinflammatory cytokines remain unclear. One of the main cytosolic sources of ROS is the enzyme NADPH oxidase (NOX), which is expressed in insulin-secreting cells $[9,10]$ and whose sole function appears to be ROS production $[11,12]$. NOX-derived ROS play a role in the physiology of insulin secretion, but their overproduction may also be involved in $\beta$-cell dysfunction [13-15]. As ROS are produced and rapidly removed by intracellular antioxidant defenses, they must be particularly important in the vicinity of their production [16]. Thus, real-time assessment of the dynamic changes in ROS levels, as well as the recognition of different sources of ROS, is of great importance.

Therefore, we sought to evaluate the involvement of both mitochondrial and cytosolic sources in the dynamics of cytokine-induced ROS production and their specific involvement in the dysfunction and death of pancreatic islet cells.

The autoimmune destruction of $\beta$-cells is the hallmark of T1D and persists for years. At the time of diagnosis, around $70-80 \%$ of $\beta$-cell mass is lost; at which point, the disease is almost irreversible [2]. Understanding the early intracellular mechanisms involved in the installation of insulitis could be the key to developing specific strategies for its modulation in an attempt to preserve $\beta$-cell function and mass and prevent disease onset. Thus, we aimed to evaluate which is the main source of oxidative stress during insulitis and the temporality of the triggered events responsible for inducing $\beta$-cell dysfunction.

\section{Materials and Methods}

\subsection{Reagents}

A culture medium with or without phenol red (RPMI 1640); dihydroethidium (DHE); Fura-2 AM and proinflammatory cytokines (IL-1 $\beta$, TNF and IFN- $\gamma$ ) from Thermo Fisher Scientific (Waltham, MA, USA); collagenase P and 4-phenylbutyric acid (4-PBA) from Sigma-Aldrich (St. Louis, MO, USA); GSK2795039 from Hycultec (Beutelsbach, Germany); a FITC Annexin V Apoptosis Detection Kit with PI from BioLegend (San Diego, CA, USA); a ViaCount kit from Merck Millipore (Burlington, MA, USA); an Insulin Ultra-Sensitive Assay kit from Cisbio (Codolet, France) and anti-p-eIF2- $\alpha$ (\#9721S), anti-p-IRE1 and anti- $\alpha$-tubulin (\#3873) antibodies from Cell Signaling Technology (Danvers, MA, USA).

\subsection{Animals}

Transgenic mice expressing a genetically encoded $\mathrm{H}_{2} \mathrm{O}_{2}$ sensor in the cytosol/nucleus (C57BL/6J/roGFP2-Orp1) or in the mitochondrial matrix (C57BL/6N/Mt-roGFP2-Orp1) were recently generated by Tobias Dick's group [17,18]. C57BL/6J wild-type (WT), NOX1 and NOX2-deficient (KO) mice were purchased from Jackson Laboratory (Bar Harbor, ME, EUA). Homozygous female NOX2 KO mice were crossbred with male roGFP2-Orp1 mice to obtain NOX2KO:roGFP2-Orp1. For proper heterozygous controls, C57BL/6J WT mice were crossbred with roGFP2-Orp1. All animals were kept in the animal facility of the Center for Integrative Physiology and Molecular Medicine (CIPMM) or in the animal facility of the Department of Physiology and Biophysics, Institute of Biomedical Sciences of University of Sao Paulo. Animals were maintained in collective cages ( $\max 4 /$ cage) at a controlled temperature $\left(23^{\circ} \mathrm{C}\right)$ in a 12-12-h light/dark cycle with free access to food/water. We used 10-20-week-old mice. For NOX2KO:roGFP2-Orp1 mice, only males were used. For the other experiments, both males and females were used.

\subsection{Glucose and Insulin Tolerance Tests (GTT and ITT)}

Mice were fasted for 10-12 h for GTT or $4 \mathrm{~h}$ for ITT. Glycemia was measured from blood collected from the tail vein at $0,10,20,40,60,90$ and $120 \mathrm{~min}$ after an i.p. injection of 
1-g glucose $/ \mathrm{kg}$ of body weight or 0.75 -IU insulin $/ \mathrm{kg}$ of body weight by a One Touch Ultra glucometer (Johnson \& Johnson).

\subsection{Isolation of Pancreatic Islets}

The animals were randomly selected for the experiments. After anesthesia with ketamine $(90 \mathrm{mg} / \mathrm{kg})$ and xylazine $(10 \mathrm{mg} / \mathrm{kg})$, followed by decapitation, the abdomen was dissected and pancreata inflated with $4 \mathrm{~mL}$ of collagenase P in Krebs-Henseleit (KH) buffer $(0.63 \mathrm{mg} / \mathrm{mL})$. After full inflation, pancreata were removed and digested for $25 \mathrm{~min}$ at $37^{\circ} \mathrm{C}$. Pancreata were then shaken manually, and the islets were washed thrice with $\mathrm{KH}$ buffer (1000 rpm/5 min). Similar-sized islets were selected and randomly distributed into wells for treatments.

\subsection{Culture of Pancreatic Islets}

Isolated islets were maintained in a RPMI 1640 medium with $10 \%(v / v)$ fetal calf serum (FCS), $1 \%$ antibiotics (100-U $/ \mathrm{mL}$ penicillin and $0.1-\mathrm{mg} / \mathrm{mL}$ streptomycin) and 10-mmol/1 D-glucose, $\mathrm{pH} 7.4,37^{\circ} \mathrm{C}$ in a humidified atmosphere of $5 \% \mathrm{CO}_{2}$ for at least $48 \mathrm{~h}$ before treatment. The islets were exposed to a combination of proinflammatory cytokines $(10-\mathrm{U} / \mathrm{mL}$ IL-1 $\beta+100-\mathrm{U} / \mathrm{mL}$ TNF $+14-\mathrm{U} / \mathrm{mL}$ IFN- $\gamma)$ for different periods, as indicated in each figure. The concentrations of the cytokines were chosen from previous studies $[5,19]$ and the standardization experiments from our group, using survival as the endpoint [20]. Additionally, in some plate reader experiments, the islets were exposed to $20 \mu \mathrm{M}$ of the NOX2 inhibitor (GSK2795039) [21] or $2.5 \mathrm{mM}$ of an attenuator of ER stress (4-PBA).

\subsection{Superoxide Measurement}

Batches of 30 islets from WT, NOX1 KO or NOX2 KO mice were incubated in $500 \mu \mathrm{L}$ of KH Buffer with $50 \mu \mathrm{M}$ of DHE dye for $20 \mathrm{~min}$ at room temperature. The supernatant was removed, and the islet cells were dispersed with trypsin for $2 \mathrm{~min}$ at $37^{\circ} \mathrm{C}$; the trypsin was then inactivated with the culture medium. The cells were pelleted $(1000 \mathrm{rpm} / 1 \mathrm{~min})$ and resuspended in $200 \mu \mathrm{L}$ of culture medium. The cell suspension was transferred to a 96-well plate and fluorescence assessed by the flow cytometer Guava EasyCyte (Millipore).

\subsection{Hydrogen Peroxide $\left(\mathrm{H}_{2} \mathrm{O}_{2}\right)$ and $\mathrm{NAD}(\mathrm{P}) \mathrm{H}$ Real-Time Measurement}

Measurements of the intracellular levels of $\mathrm{H}_{2} \mathrm{O}_{2}$ and $\mathrm{NAD}(\mathrm{P}) \mathrm{H}$ were performed every $10 \mathrm{~min}$ for $22 \mathrm{~h}$, using the CLARIOstar Microplate Reader (BMG LABTECH, Ortenberg, Germany). The internal temperature was set at $37^{\circ} \mathrm{C}$ and atmospheric conditions at $5 \%$ $\mathrm{CO}_{2}$, with open ventilation for free $\mathrm{O}_{2}$ diffusion in the system. Batches of 25 islets/well were transferred to U-bottom 96-well plates containing $200 \mu \mathrm{L}$ of preheated islet medium without phenol red with or without cytokines. Cytosolic and mitochondrial roGFP2 emission in the roGFP2-Orp1 and Mt-roGFP2-Orp1 islets was detected after excitation at 405 and $488 \mathrm{~nm}$ and emission at $530 \mathrm{~nm}$. Fluorescence from the roGFP2-Orp1 and MtroGFP2-Orp1 islets was normalized by subtracting the background fluorescence emitted from the WT islets (without the sensor) at the respective conditions. The results are shown as a $405 / 488-\mathrm{nm}$ ratio. $\mathrm{NAD}(\mathrm{P}) \mathrm{H}$ autofluorescence was detected after excitation at $340 \mathrm{~nm}$ and emission at $450 \mathrm{~nm}$, as previously described [22,23]. In addition, in some experiments, the islets were preincubated for two hours with 20- $\mu \mathrm{M}$ GSK2795039 or for five hours with 2.5-mM 4-PBA, prior to the addition of cytokines. Of note, the inhibitors were also present during the plate reader experiment.

\subsection{Paraffin Infiltration and Sections}

Islets from NOX2KO:roGFP2-Orp1 mice were cultured in the absence or presence of cytokines for $4 \mathrm{~h}$ and $30 \mathrm{~min}$. Measurements of the intracellular $\mathrm{H}_{2} \mathrm{O}_{2}$ levels were made using a redox histology approach, as previously described $[17,23]$. Batches of 30 islets were collected and immersed in 50-mM N-ethyl-maleimide (NEM) dissolved in PBS for $20 \mathrm{~min}$ for sensor chemical fixation. The NEM was then removed and islets fixed in $4 \%$ 
paraformaldehyde for $30 \mathrm{~min}$. After paraformaldehyde removal, the islets were incubated in 100- $\mu$ L HepatoQuick (Roth, Karlsruhe, Germany) mixed with human citrate plasma $(1: 2 \mathrm{v} / \mathrm{v})$ and $1 \% \mathrm{CaCl}_{2}$ for $1 \mathrm{~h}$ at $37{ }^{\circ} \mathrm{C}$. Clots were then incubated in $95 \%$ ethanol at $4{ }^{\circ} \mathrm{C}$ overnight and dehydrated in ethanol prior to paraffin embedding. The paraffinembedded clots were sectioned (3- $\mu \mathrm{m}$ thick) with a semi-automated rotary microtome (Leica Biosystems, Wetzlar, Germany) and placed on silanized glass slides. Images of all the islets in each slide were obtained by the Axio Observer 7 fluorescence microscope (Zeiss, Oberkochen, Germany) with a 63x objective in both $405 \mathrm{~nm}$ and $488 \mathrm{~nm}$. The images were analyzed with ImageJ Fiji Software, and the ratio (405/488 nm) was used to compare different groups.

\subsection{Insulin Secretion}

Batches of 10 similar-sized islets were selected and checked for the insulin secretion assay, as previously described $[23,24]$. Briefly, islets were incubated in $\mathrm{KH}$ buffer with $2.8-\mathrm{mM}$ glucose at $37^{\circ} \mathrm{C}$ for $30 \mathrm{~min}$. The supernatant was discarded and islets were incubated at $37^{\circ} \mathrm{C}$ for $60 \mathrm{~min}$ with a $\mathrm{KH}$ buffer in a low $(5.6 \mathrm{mM})$ or high $(16.7 \mathrm{mM})$ glucose concentration. The supernatant was collected for insulin measurements. The islets were then pooled for each condition ( $24 \mathrm{~h}$ or $48 \mathrm{~h}$ ) and disrupted in an acid-ethanol solution (52 mL ethanol : $17 \mathrm{~mL}$ water : $1 \mathrm{~mL}$ hydrochloric acid) to obtain the intracellular insulin content. Insulin was measured by a Fluorescence Resonance Energy Transfer (FRET) using the Insulin Ultra-Sensitive Assay kit (Cisbio).

\subsection{0. $\mathrm{Ca}^{2+}$ Measurements}

After treatment, the islets from WT and NOX2 KO mice were checked for $\mathrm{Ca}^{2+}$ homeostasis using two protocols: (i) measurements of the total cytosolic $\mathrm{Ca}^{2+}$ levels and (ii) evaluation of the Store-Operated $\mathrm{Ca}^{2+}$ Entry (SOCE), as previously described [25]. For both protocols, the islets were incubated with 5- $\mu \mathrm{M}$ Fura-2 AM for $2 \mathrm{~h}$ in bicarbonate-buffered Krebs solution and placed under the fluorescence microscope Axio Observer 7 (Zeiss, Oberkochen, Germany). Measurements were made every $2 \mathrm{~s}$ for $20 \mathrm{~min}$. For protocol (i), the islets were first incubated in a buffer without glucose, followed by the addition of high glucose $(20 \mathrm{mM})$. The steepness of the curve after a glucose addition was calculated using the Gompertz equation: $y=a * \exp (-\exp (-\mathrm{k} *(\mathrm{x}-\mathrm{xc})))$; $\mathrm{a}=$ amplitude; $\mathrm{xc}=$ center; $\mathrm{k}=$ steepness). For protocol (ii), the islets were first incubated in a buffer without glucose and $\mathrm{Ca}^{2+}$. After that, 3- $\mu \mathrm{M}$ thapsigargin was added to the empty ER $\mathrm{Ca}^{2+}$ stores. Finally, the islets were exposed to $3-\mu \mathrm{M}$ thapsigargin $+2-\mathrm{mM} \mathrm{Ca}^{2+}$ to evaluate the extracellular $\mathrm{Ca}^{2+}$ influx by SOCE. Throughout the entire experiment, a glucose-free medium was used to avoid activation of the voltage-dependent $\mathrm{Ca}^{2+}$ channels. Cytosolic $\mathrm{Ca}^{2+}$ from individual islets was imaged using excitation at 340/380 $\mathrm{nm}$ and emission at $505 \mathrm{~nm}$.

\subsection{ER Stress Markers}

The total protein extracts were separated by SDS-PAGE and transferred to nitrocellulose membranes. The membranes were probed with specific antibodies against p-eIF2- $\alpha$ and p-IRE1, using $\alpha$-tubulin as the internal control, as previously described [23,26,27]. The antibodies were diluted (1:1000) in Tris-Buffered Saline with Tween buffer. One representative blot is shown.

\subsection{Cell Death Assays}

The viability was assessed by two protocols: the Guava ViaCount Reagent (Millipore), which distinguishes between viable, apoptotic and dead cells, and the FITC Annexin V Apoptosis Detection Kit with PI (BioLegend, San Diego, CA, USA). We used batches of 30 islets/condition. The protocols were performed following their respective manufacturers' instructions, and the fluorescence was assessed by flow cytometry. For each individual experiment, the values were normalized by dividing the fluorescence of the islets exposed 
to cytokines by the average fluorescence of the respective untreated islets in same genotype. The values are indicated as arbitrary units (A.U.).

\subsection{Statistical Analysis}

The results are presented as the mean \pm SD of at least three independent experiments, as described in the figure legends. The statistical analyses were performed in GraphPad Prism 8 software. A Student's $t$-test was used to compare the differences between the cytokine-treated islets and respective control islets from the same genotypes. One-way ANOVA followed by Dunnett's, Sidak's or Tukey's tests were used to compare multiple groups, and a two-way ANOVA + Dunnett's test was used to compare multiple interrelated measurements between the groups, with the confidence levels set to $p<0.05$.

\section{Results}

3.1. Proinflammatory Cytokines Increase the Cytosolic/Nuclear, but Not the Mitochondrial, $\mathrm{H}_{2} \mathrm{O}_{2}$ Levels

First, we sought to systematically analyze the ROS production upon exposure to proinflammatory cytokines. Therefore, we cultured mice islets with a combination of proinflammatory cytokines based on previous studies $[5,19]$ and monitored the static superoxide $\left(\mathrm{O}_{2}{ }^{\bullet-}\right)$ production at different time points by flow cytometry using the chemical probe dihydroethidium (DHE). The cytokines induced increased $\mathrm{O}_{2}{ }^{\bullet-}$ production between 2 and $8 \mathrm{~h}$, being statistically significant at $2 \mathrm{~h}$ and returning to the basal levels after $24 \mathrm{~h}$ of exposure (Figure 1A).

We then followed up to evaluate the $\mathrm{H}_{2} \mathrm{O}_{2}$ production in different cellular compartments using a state-of-art, genetically encoded redox sensor, roGFP2-Orp1, targeted at the mitochondrial matrix (Mt-roGFP2-Orp1) or the cytosol/nucleus (roGFP2-Orp1). With these sensors, we aimed to gain further insights into the source and time-based changes of ROS production. We thus isolated islets from Mt-roGFP2-Orp1 and roGFP2-Orp1 mice and exposed them to different cytokine mixes (Figures 1 and S1). RoGFP2-Orp1 oxidation, reflecting changes in the $\mathrm{H}_{2} \mathrm{O}_{2}$ levels, was monitored in real time for $22 \mathrm{~h}$ under atmospheric controlled conditions using a dedicated plate reader [23,27] (see Methods). Simultaneously, the changes in intracellular $\mathrm{NAD}(\mathrm{P}) \mathrm{H}$ were also assessed by measuring its autofluorescence. After the cytokine addition, we observed increased $\mathrm{H}_{2} \mathrm{O}_{2}$ production in the cytosol/nucleus of islet cells between 3 and $6 \mathrm{~h}$, which reached the maximum levels at $4.5 \mathrm{~h}$, relative to the untreated islets (Figure 1B,C). Interestingly, the cytokines did not increase the $\mathrm{H}_{2} \mathrm{O}_{2}$ production in the mitochondrial matrix (Figure 1D,E) relative to the untreated islets. However, we observed that, in mitochondria, the $\mathrm{H}_{2} \mathrm{O}_{2}$ levels tend to increase over time, probably due to glucose usage [18,28].

A

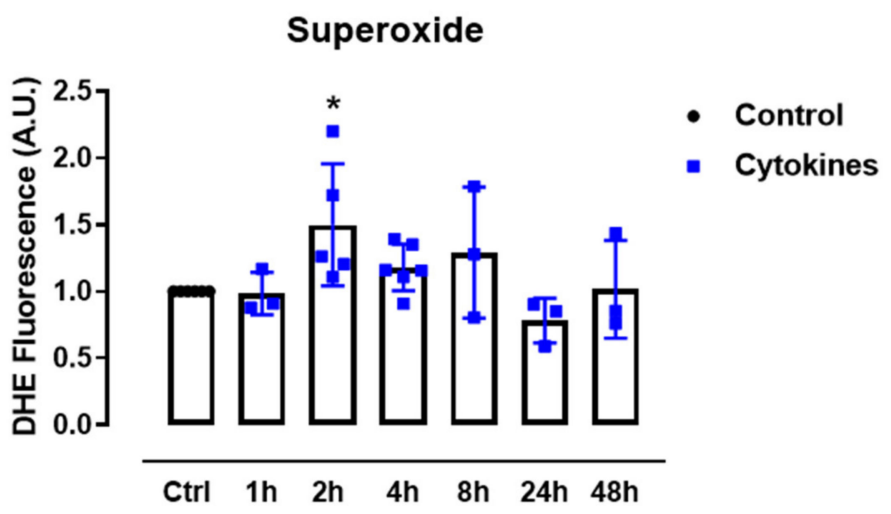

Figure 1. Cont. 
B

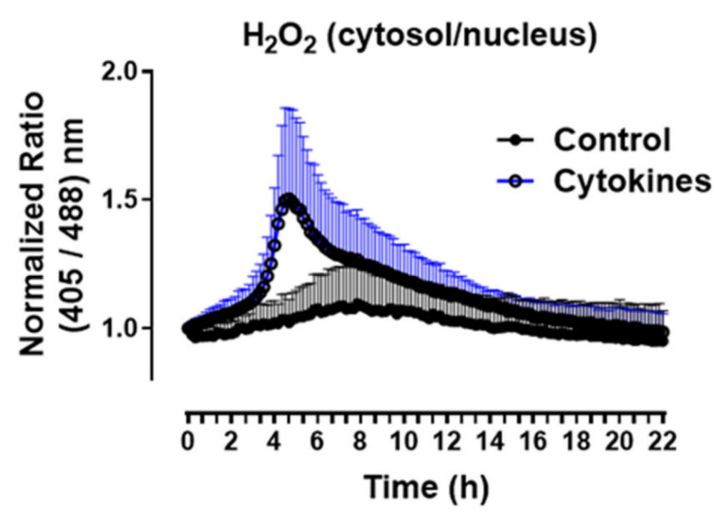

D

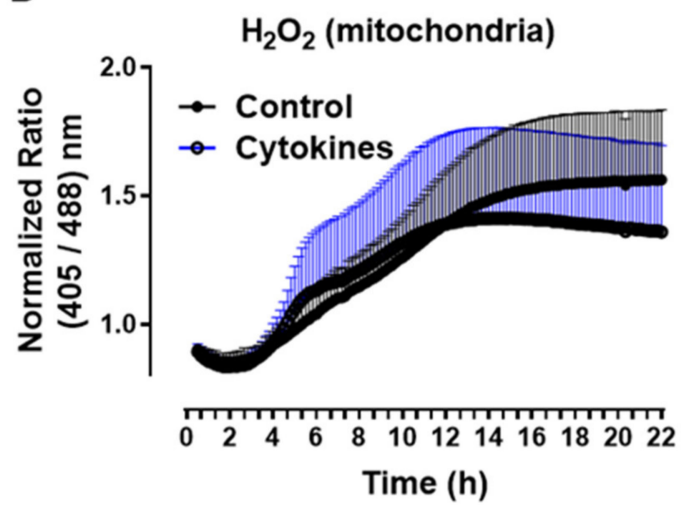

F

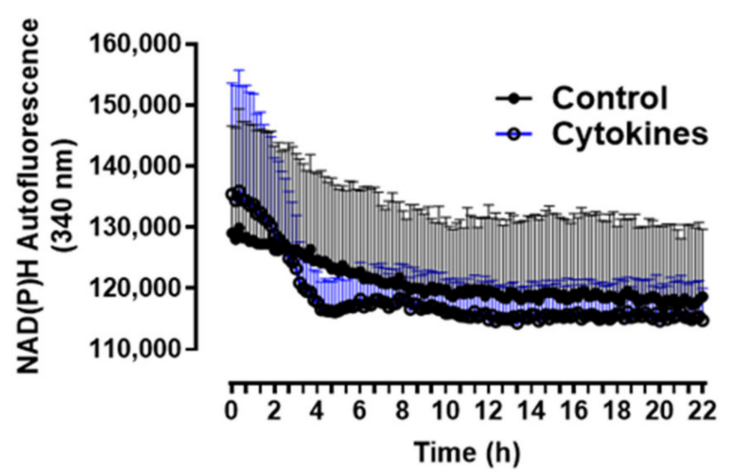

C

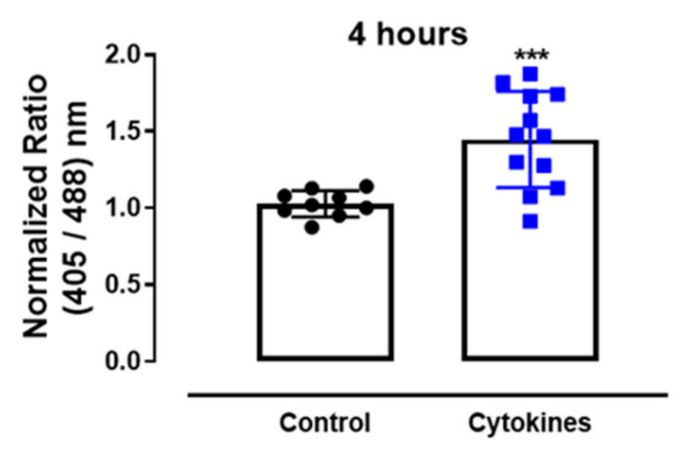

E

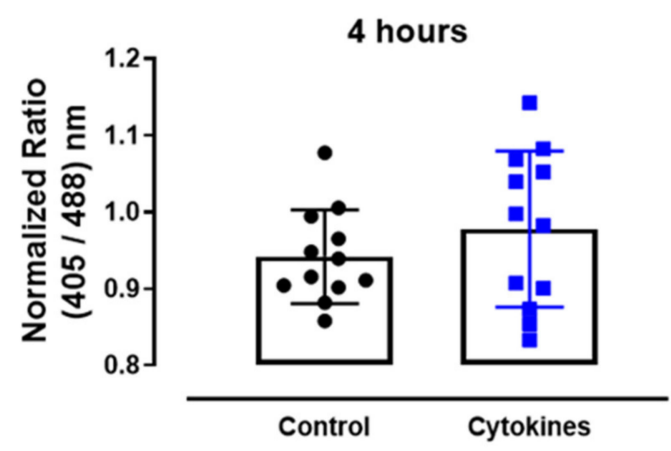

G

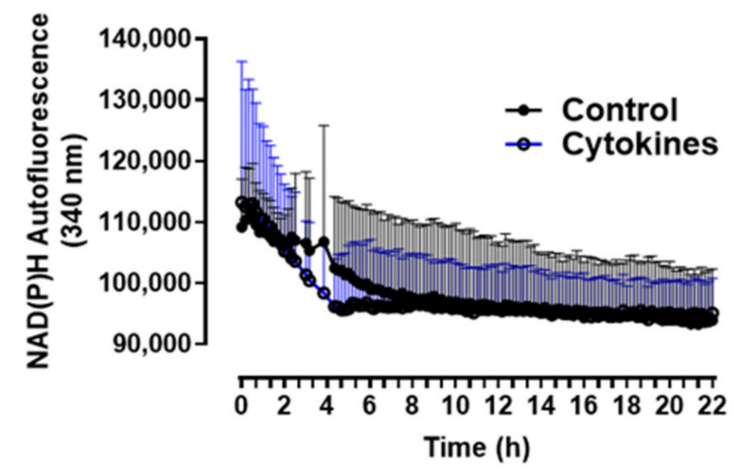

Figure 1. ROS production in pancreatic islets exposed to proinflammatory cytokines. (A) Superoxide production from wildtype islets in the absence (Ctrl) or presence of proinflammatory cytokines after different periods of exposure, as indicated. The fluorescence intensity was analyzed by flow cytometry using DHE dye. The results are expressed as the mean \pm SD of 3-6 independent experiments. A.U.: arbitrary units. (B) Dynamic levels of the cytosolic/nuclear $\mathrm{H}_{2} \mathrm{O}_{2}$ of islets from roGFP2Orp1 mice incubated with proinflammatory cytokines. (C) Peak of the normalized ratio of (B) at $4 \mathrm{~h}$. (D) Dynamic levels of mitochondrial $\mathrm{H}_{2} \mathrm{O}_{2}$ of the islets from Mt-roGFP2-Orp1 mice incubated with proinflammatory cytokines. (E) Peak of the normalized ratio of (D) at $4 \mathrm{~h}$. The fluorescence intensity was captured every $10 \mathrm{~min}$ for $22 \mathrm{~h}$. The results are presented as the normalized ratio $(405 / 488 \mathrm{~nm})$ and mean \pm SD of triplicates from 3 to 4 independent experiments. (F,G) Dynamic levels of NAD $(\mathrm{P}) \mathrm{H}$ of the islets from roGFP2-Orp1 (F) and Mt-roGFP2-Orp1 (G) mice incubated with proinflammatory cytokines. The results are presented as the mean \pm SD of triplicates from 3 to 4 independent experiments. ${ }^{*} p<0.05$ and ${ }^{* * *} p<0.001$ when compared to the control using One-Way ANOVA + Dunnett's (A) or a Student's $t$-test (C). Proinflammatory cytokines mix: $10-\mathrm{U} / \mathrm{mL}$ IL-1 $\beta+100-\mathrm{U} / \mathrm{mL}$ TNF $+14-\mathrm{U} / \mathrm{mL}$ IFN- $\gamma$.

Interestingly, concomitant with the peak of cytosolic $\mathrm{H}_{2} \mathrm{O}_{2}$ production, we observed a decrease in the $\mathrm{NAD}(\mathrm{P}) \mathrm{H}$ levels after cytokine exposure independent of the genetic 
background (Figure 1F,G). Other cytokine combinations (varying concentrations of IL-1 $\beta$, TNF and INF- $\gamma$ ) also led to similar results, with small differences in the maximal effect, however (Figure S1).

\subsection{NOX2 Pharmacological Inhibition or Genetic Deletion Abolishes Cytokine-Induced Cytosolic} $\mathrm{O}_{2}{ }^{\bullet-}$ and $\mathrm{H}_{2} \mathrm{O}_{2}$ Production

The experiments above show that static $\mathrm{O}_{2}{ }^{\bullet-}$ production was increased after $2-4 \mathrm{~h}$ of cytokine exposure in C57BL/6J wild-type (WT) islets, returning to the basal levels after $24 \mathrm{~h}$ (Figure 1A), which was paralleled by the $\mathrm{H}_{2} \mathrm{O}_{2}$ measurements with roGFP2-Orp1. As there were no significant changes in the mitochondrial $\mathrm{H}_{2} \mathrm{O}_{2}$ production in cytokine-treated islets, our data suggests that the cytosol is the main source of ROS in cytokine-induced oxidative stress. One of the main sources of cytosolic $\mathrm{O}_{2}{ }^{--}$and $\mathrm{H}_{2} \mathrm{O}_{2}$ are the NADPH-oxidases (NOX). Therefore, we aimed to investigate the contribution of two important NOXs for cytokine-induced $\mathrm{O}_{2}{ }^{\bullet-}$ production, using NOX1 KO and NOX2 $\mathrm{KO}$ islets. Interestingly, we observed that the genetic deletion of NOX2, but not of NOX1, prevents a cytokine-induced increase in $\mathrm{O}_{2}{ }^{\bullet-}$ (Figure 2A).

This suggests that NOX2 is the main NOX isoform responsible for $\mathrm{O}_{2}{ }^{\bullet-}$ production upon cytokine exposure. To evaluate whether the absence of NOX2 influences the cytosolic $\mathrm{H}_{2} \mathrm{O}_{2}$ production, as it prevents $\mathrm{O}_{2}^{\bullet-}$, we cotreated the roGFP2-Orp1 islets with cytokines and a specific NOX2 inhibitor, GSK2795039 (GSK) [21]. We observed that the inhibition of NOX2 prevents a cytokine-induced cytosolic $\mathrm{H}_{2} \mathrm{O}_{2}$ increase (Figure 2B). To confirm this data, we crossbred NOX2 KO mice with mice expressing roGFP2-Orp1, generating the transgenic mice NOX2 KO:roGFP2-Orp1, in which NOX2 is deleted and the roGFP2-Orp1 sensor is expressed. As these mice are heterozygous for roGFP2-Orp1, the fluorescence levels are not optimal for real-time monitoring in the plate reader, which requires strong sensor expression [29]. Thus, we performed a redox histology approach, previously designed by our group $[17,23]$ and used by others $[30,31]$, which has been shown to reflect in vivo changes in the $\mathrm{H}_{2} \mathrm{O}_{2}$ levels. We exposed islets to cytokines for $4 \mathrm{~h}$ and $30 \mathrm{~min}$, since the maximum peak of cytosolic $\mathrm{H}_{2} \mathrm{O}_{2}$ production was observed at this time in the real-time assessments (Figure 1B). Consistent with our real-time experiments, we observed here that cytokines increase the cytosolic/nuclear $\mathrm{H}_{2} \mathrm{O}_{2}$ levels in WT islets (Figure 2C,D). Consistent with the $\mathrm{O}_{2}{ }^{\bullet-}$ measurements in NOX KO islets (Figure 2A) and with the $\mathrm{H}_{2} \mathrm{O}_{2}$ real-time measurements in GSK-treated islets (Figure 2B), the cytokines did not increase $\mathrm{H}_{2} \mathrm{O}_{2}$ production in the NOX2 KO:roGFP2-Orp1 islets (Figure 2C,D).

In summary, both NOX2 pharmacological inhibition and genetic ablation leads to lower cytosolic $\mathrm{O}_{2}{ }^{\bullet-}$ and $\mathrm{H}_{2} \mathrm{O}_{2}$ production upon the cytokine treatment, implicating NOX2 in cytokine-induced oxidative stress.

A

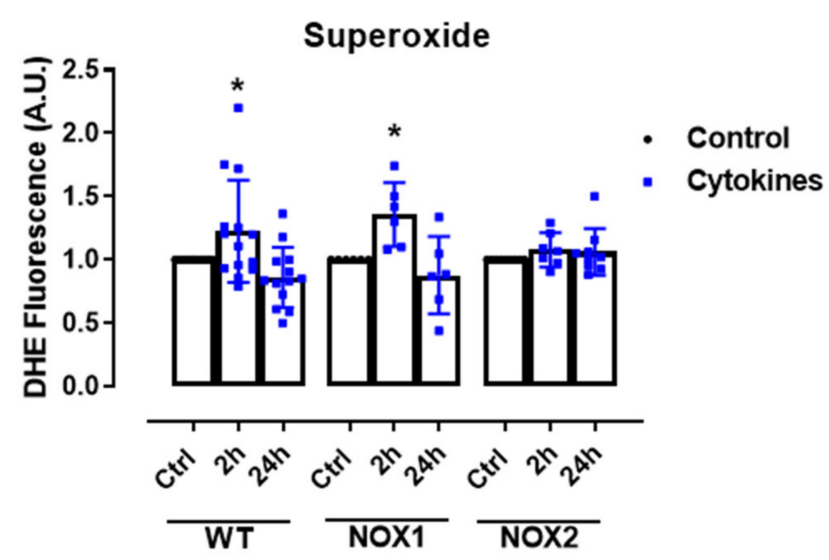

B

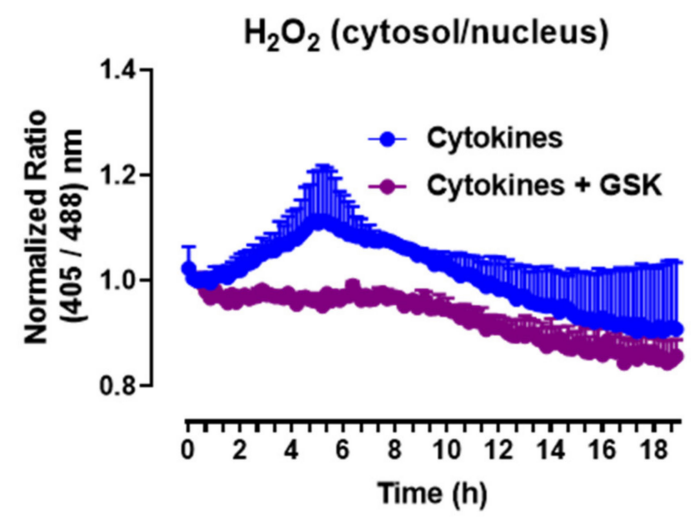

Figure 2. Cont. 
C

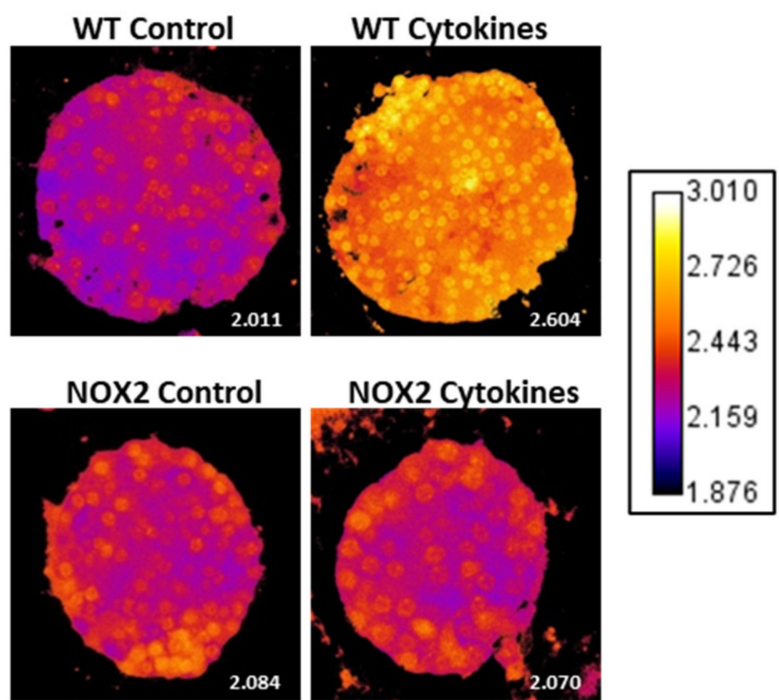

D

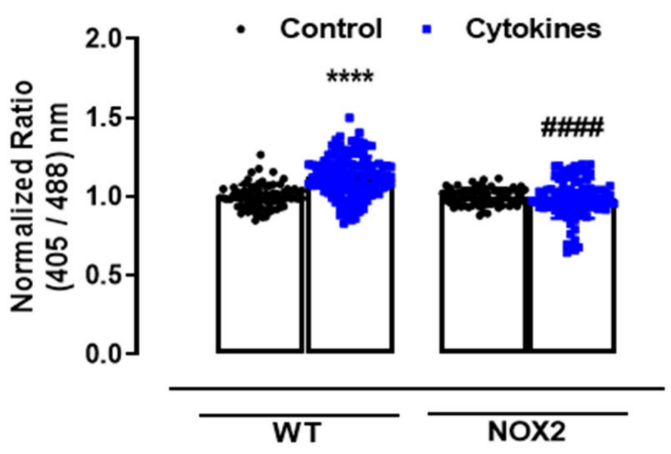

Figure 2. The role of NOX2 in the ROS production of pancreatic islets exposed to proinflammatory cytokines. (A) Superoxide production from wild-type (WT), NOX1 KO (NOX1) or NOX2 KO (NOX2) islets in the absence (Ctrl) or presence of proinflammatory cytokines after different periods of exposure, as indicated. The fluorescence intensity was analyzed by flow cytometry using DHE dye. The results are presented as the mean \pm SD of 6-14 independent experiments. A.U.: arbitrary units. (B) Dynamic levels of cytosolic/nuclear $\mathrm{H}_{2} \mathrm{O}_{2}$ of the islets from roGFP2-Orp1 mice incubated with proinflammatory cytokines in the absence or presence of $20 \mu \mathrm{M}$ of the NOX2 inhibitor GSK2795039 (GSK). The fluorescence intensity was captured every $10 \mathrm{~min}$ for $18 \mathrm{~h}$. The results are presented as the normalized ratio $(405 / 488 \mathrm{~nm})$ and mean $\pm \mathrm{SD}$ of 3 independent experiments. (C,D) NOX2 KO mice and roGFP2-Orp1 mice were crossbred in order to obtain NOX2KO:roGFP2Orp1. C57BL/6J WT mice and roGFP2-Orp1 mice were crossbred in order to obtain proper heterozygous controls. The islets were incubated in the absence (Ctrl) or presence of proinflammatory cytokines for $4 \mathrm{~h}$ and $30 \mathrm{~min}$. (C) Representative images of the islets from the control heterozygous (WT) and NOX2KO:roGFP2-Orp1 (NOX2) mice. The color temperatures reflect the normalized 405/488 ratio, from black/purple (non-oxidized sensor) to yellow/white (completely oxidized sensor), thus reflecting the $\mathrm{H}_{2} \mathrm{O}_{2}$ levels. (D) $\mathrm{H}_{2} \mathrm{O}_{2}$ levels represented as the normalized ratio (405/488). The results are expressed as the mean \pm SD of individual islets from $6-9$ independent experiments. (A) ${ }^{*} p<0.05$ when compared to the Ctrl. One-Way ANOVA + Sidak. (D) ${ }^{* * * *} p<0.0001$ versus the respective controls in same genotypes; \#\#\# $p<0.0001$ versus the WT cytokines. One-Way ANOVA + Tukey's. Proinflammatory cytokines mix: 10-U/mL IL-1 $\beta+100-\mathrm{U} / \mathrm{mL}$ TNF + 14-U/mL IFN- $\gamma$.

\subsection{Absence of NOX2 Is Beneficial against Cytokine-Induced $\beta$-Cell Dysfunction and Death}

To understand whether NOX2 deletion and decreased cytosolic ROS production protects islets from cytokine-induced dysfunction, we next analyzed the insulin secretion and insulin content from WT and NOX2 KO islets after 24 and $48 \mathrm{~h}$ of cytokine exposure (Figure 3A-C).

As expected, the cytokines decreased the insulin secretion and insulin content in WT islets after 24 and $48 \mathrm{~h}$ (Figure 3A-C). This was not observed in the NOX2 KO islets exposed to the cytokines (Figure 3A-C). Additionally, NOX2 KO mice had better glucose tolerance compared to WT mice, presenting statistically significant lower glycemia at early time points, between 10 and 40 min (Figure 3D), reflecting in a lower area under the curve (AUC) (Figure 3E). NOX1 mice, however, had the same profile as WT mice during GTT (Figure 3D). To investigate whether these animals were more sensitive to insulin, we performed an insulin tolerance test (ITT). We observed no differences between WT and NOX1 KO or WT and NOX2 KO mice in the glycemia curve after the injection of insulin (Figure 3F), reflected in similar AUC between the groups (Figure 3G). We also observed similar glucose disappearance rates (kITT) between the groups (Figure $3 \mathrm{H}$ ). We, therefore, concluded that the NOX2 KO mice presented better glycemic levels, and this was not due to better insulin action in the peripheral tissues. Instead, it reflected a better secretory capacity in the islets, consistent with ex vivo experiments. 
Finally, we exposed WT and NOX2 KO islets to cytokines and monitored the cell death by flow cytometry using two different assays. The values were indicated as the fold change of the respective control (Figure $4 \mathrm{~A}, \mathrm{~B}$ ). As expected, the cytokines led to a two-fold increase in cell death in WT islets after $48 \mathrm{~h}$ (Figure $4 \mathrm{~A}, \mathrm{~B}$ ). In terms of percentage, this represents $\sim 6-12 \%$ in the WT islets in the control condition and $\sim 16-20 \%$ in the WT islets exposed to cytokines for $48 \mathrm{~h}$. Although we observed that NOX2 KO islets in the control conditions had an increased basal cell death compared to WT islets $(\sim 18 \%$ in NOX2 KO islets and $\sim 6-12 \%$ in WT islets), incubation for $48 \mathrm{~h}$ with the cytokines did not lead to an additional increase of cell death and, therefore, the absence of NOX2 protected from cytokine-induced cell death.

\section{A}

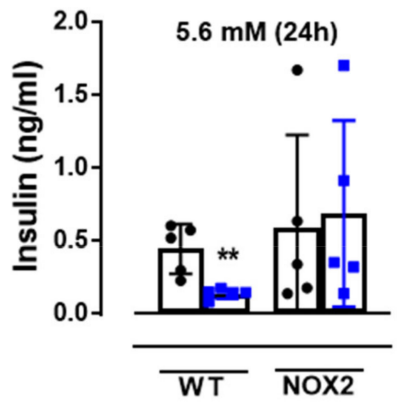

Insulin secretion

- Control

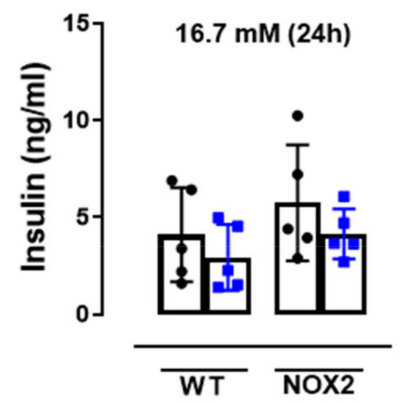

B

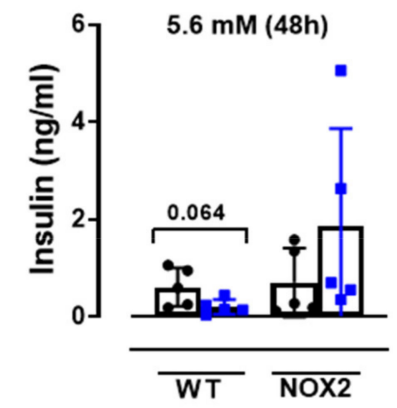

Insulin secretion

- Control - Cytokines

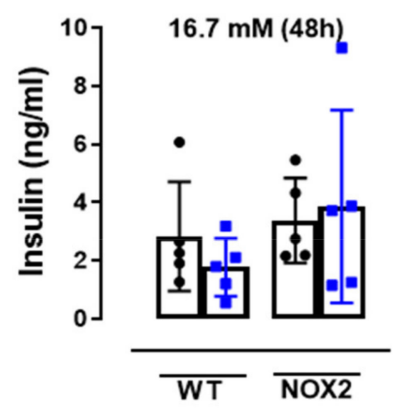

C

Insulin content

- Control

- Cytokines
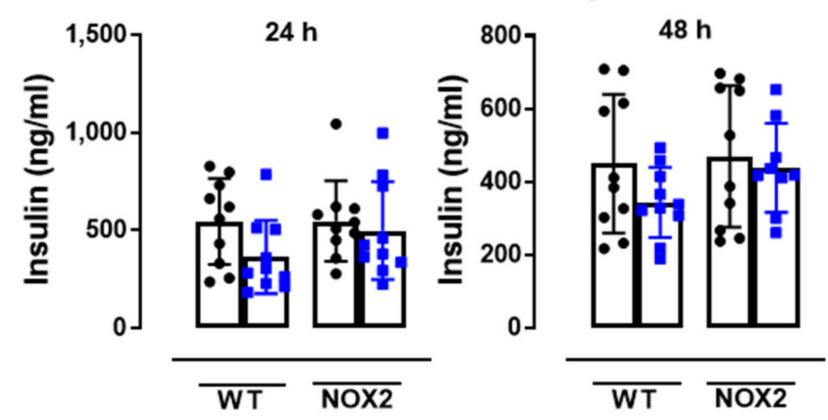

Figure 3. Cont. 
D

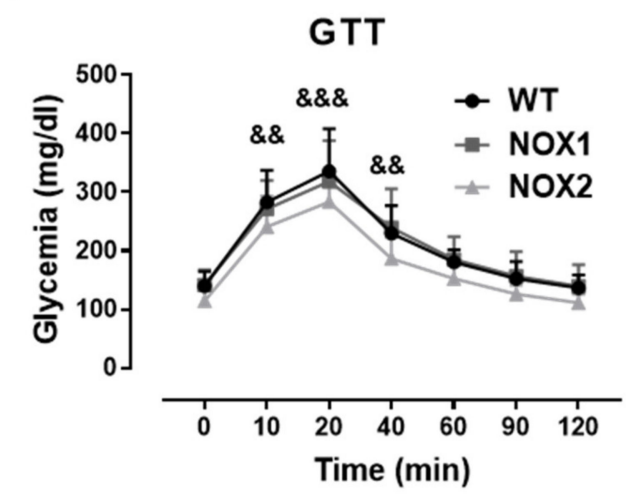

F

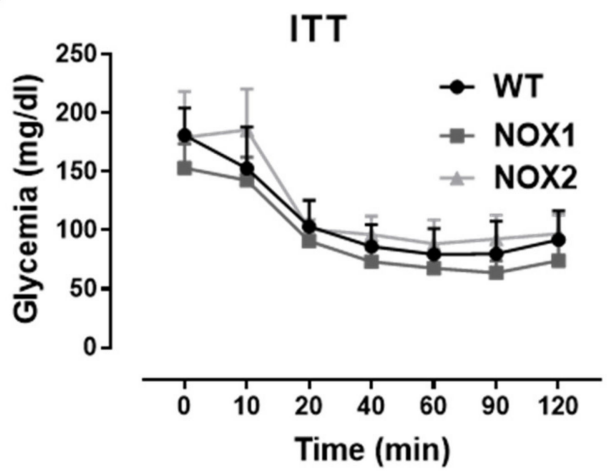

E

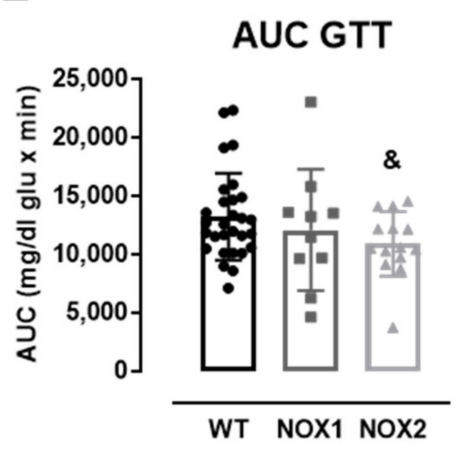

G

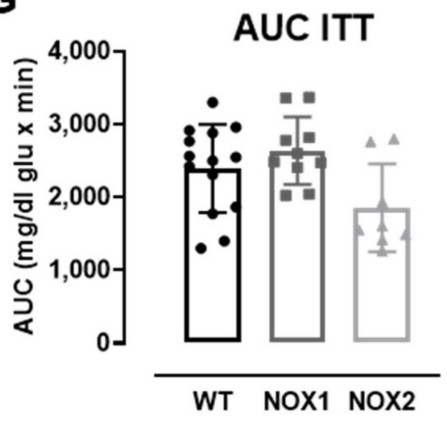

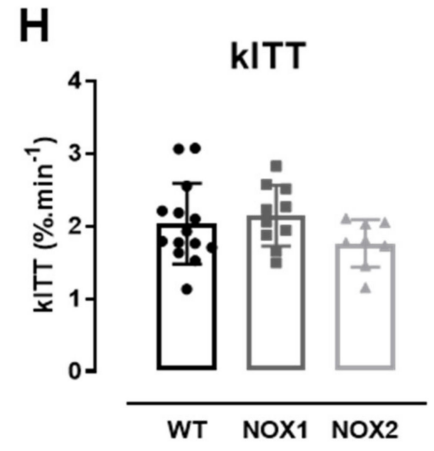

Figure 3. The role of NOX2 in islet function in vivo and ex vivo. (A,B) The insulin secretion of islets from WT and NOX2 KO (NOX2) islets exposed to a proinflammatory cytokine mix (10-U/mL IL-1 $\beta+100-\mathrm{U} / \mathrm{mL} \mathrm{TNF}+14-\mathrm{U} / \mathrm{mL}$ IFN- $\gamma$ ). The islets were cultured in 10-mM glucose for 24 (A) or $48 \mathrm{~h} \mathrm{(B)} \mathrm{and} \mathrm{then} \mathrm{incubated} \mathrm{with} 5.6$ or $16.7 \mathrm{mM}$ of glucose for $1 \mathrm{~h}$. The results are expressed as the mean $\pm \mathrm{SD}$ of 5 independent experiments. ${ }^{* *} p<0.01$ versus the respective control of the same genotypes using a Student's $t$-test. (C) Intracellular insulin contents of the WT and NOX2 islets in (A,B). After the insulin secretion assay, the islets were pooled for each condition $(24 \mathrm{~h}$ or $48 \mathrm{~h})$ and disrupted in a solution of acid-ethanol for an analysis of the intracellular contents of insulin. The results are expressed as the mean \pm SD of 5 independent experiments. (D,E) The Glucose Tolerance Test (GTT) of WT, NOX1 KO (NOX1) and NOX2 KO (NOX2) mice. The animals were fasted for 10-12 h. The glycemia was then measured from the tail vein using a glucometer at time zero (0) and after the i.p. administration of glucose (1-g glucose/ kg) at 10, 20, 40, 60, 90 and $120 \mathrm{~min}$. (D) GTT curve (mg/dl). (E) Area under the curve (AUC) of (D). The results are expressed as the mean \pm SD of 29, 10 and 14 animals for WT, NOX1 KO and NOX2 KO, respectively. (F-H) The Insulin Tolerance Test (ITT) of WT, NOX1 KO (NOX1) and NOX2 KO (NOX2) mice. The animals were fasted for $4 \mathrm{~h}$. The glycemia was then measured from the tail vein at time zero (0) and after the i.p. administration of insulin (0.75-U insulin/ kg) at 10, 20, 40, 60, 90 and $120 \mathrm{~min}$. (F) ITT curve (mg/dl). (G) AUC of (F). (H) K expressed as the mean \pm SD of 14, 10 and 8 animals for WT, NOX1 KO and NOX2 KO, respectively. \& $p<0.05, \& \& p<0.01$ and ${ }^{\& \& \&} p<0.001$ represent NOX2 versus WT using a two-way ANOVA + Dunnett's (D) or a Student's $t$-test (E). 
A

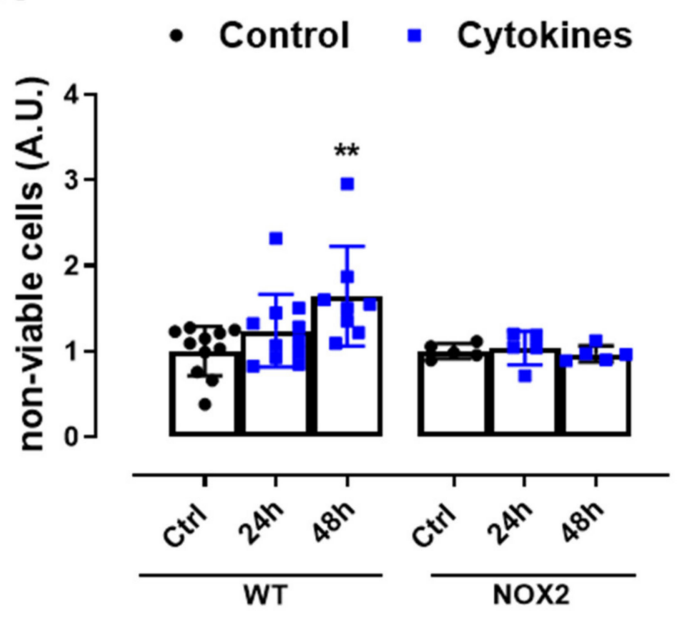

B

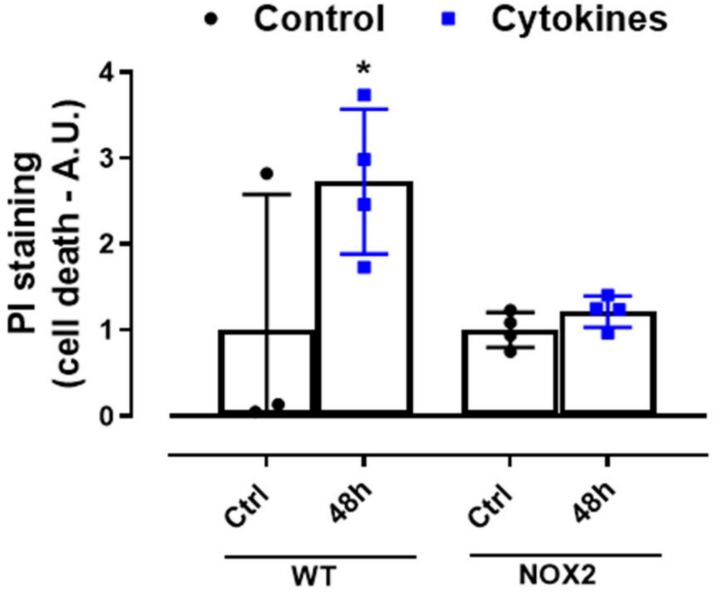

Figure 4. The viability of the islets from C57BL/6J (WT) and NOX2 KO (NOX2) mice exposed to proinflammatory cytokines. $(\mathbf{A}, \mathbf{B})$ The apoptosis of islets from WT and NOX2 KO mice after 24 or $48 \mathrm{~h}$ of incubation in 10-mM glucose in the absence (Control) or presence of a proinflammatory cytokine mix (10-U/mL IL-1 $\beta+100-\mathrm{U} / \mathrm{mL}$ TNF $+14-\mathrm{U} / \mathrm{mL}$ IFN- $\gamma)$. The apoptosis was assessed by flow cytometry using a ViaCount kit (A) or propidium iodide (PI) staining (B). For each individual experiment, the values were normalized by dividing the fluorescence of the islets exposed to cytokines by the average fluorescence of the respective untreated islets from the same genotype. The values are indicated as the fold change. The results are expressed as the mean \pm SD of 5-11 (A) or 3 to 4 (B) independent experiments. ${ }^{*} p<0.05$ and ${ }^{* *} p<0.01$ versus the respective control of the same genotypes. One-way ANOVA + Dunnett's.

3.4. NOX2 Knockout Does Not Protect from the Cytokines-Induced Impairment of Cytosolic Ca ${ }^{2+}$ Homeostasis and Does Not Interfere with the SOCE Mechanism

One important step for insulin secretion is the cytosolic $\mathrm{Ca}^{2+}$ influx upon glucose exposure. Thus, we next checked the cytosolic $\mathrm{Ca}^{2+}$ dynamics in the WT and NOX2 KO islets after $24 \mathrm{~h}$ of cytokine exposure. Cytosolic $\mathrm{Ca}^{2+}$ in the WT and NOX2 KO islets in the resting state (resting calcium, Figure 5A,B) with a glucose-free buffer (G0) was similar, independent of the genotype or treatment. Subsequently, the addition of glucose at $20 \mathrm{mM}$ (G20), as expected, increased the cytosolic $\mathrm{Ca}^{2+}$ in the WT islets, which was impaired by cytokine pre-exposure (Figure 5A,C). Surprisingly, despite NOX2 KO alleviating the cytokine-induced glucose-stimulated insulin secretion (GSIS) dysfunction (Figure 3A,B), NOX2 KO had no impact in the cytokine-induced dysfunction of the glucose-stimulated $\mathrm{Ca}^{2+}$ influx (Figure 5A,C). The steepness of the curve after glucose addition, calculated using the Gompertz equation, was affected by the cytokine treatment in both genotypes1.64 and 1.57 in the untreated WT and NOX KO islets, respectively, and 0.62 and 0.79 in the cytokine-treated WT and NOX2 KO islets, respectively - thus demonstrating a slower response to glucose.

Next, we evaluated the mechanism of ER $\mathrm{Ca}^{2+}$ replenishment, known as storeoperated calcium entry (SOCE). For that, we first applied 5- $\mu \mathrm{M}$ thapsigargin to deplete the ER Ca ${ }^{2+}$ stores completely in a glucose $/ \mathrm{Ca}^{2+}$-free solution (Figure $5 \mathrm{D}, 5 \mathrm{~min}$, first arrow). This was followed by the addition of extracellular 2-mM Ca${ }^{2+}$ (Figure 5D, $12 \mathrm{~min}$, second arrow) to provoke an extracellular $\mathrm{Ca}^{2+}$ influx through STIM-ORAI, as described previously [25,32]. We observed that $24 \mathrm{~h}$ of the cytokine treatment leads to a higher peak of $\mathrm{Ca}^{2+}$ in both the WT and NOX2 KO islets in a similar fashion (Figure 5D,E), indicating no participation of NOX2 in the SOCE mechanism. This also suggests that cytokines cause alterations in the $\mathrm{ER} \mathrm{Ca}^{2+}$ stores, and this effect can be compensated by increasing the extracellular $\mathrm{Ca}^{2+}$ influx [33]. 
A

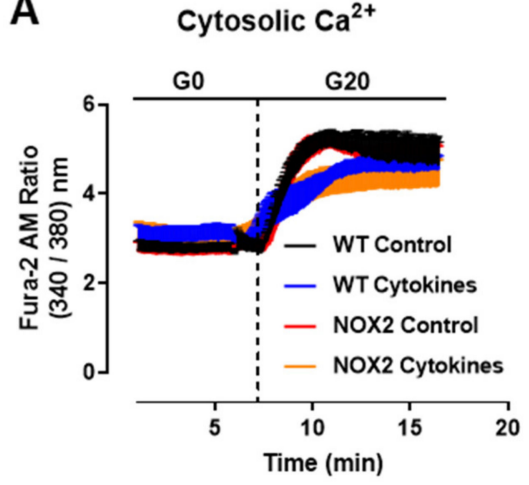

D

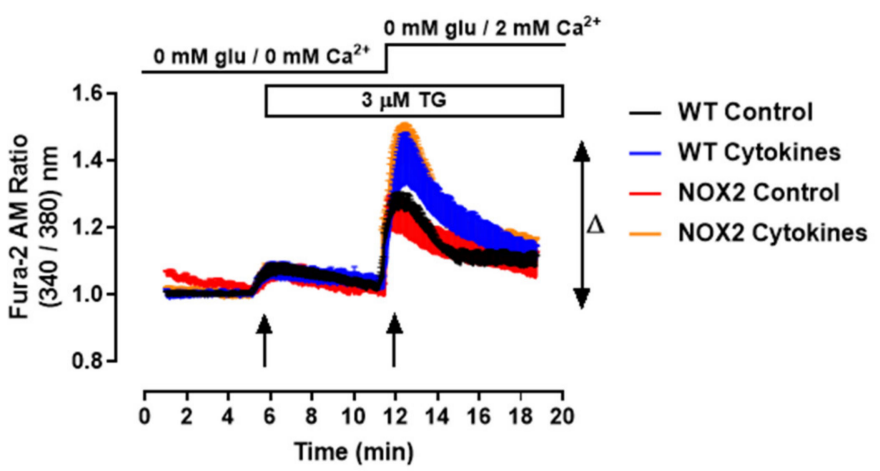

B

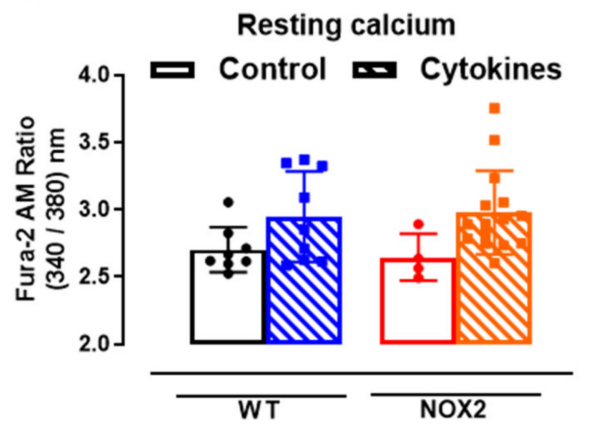

C

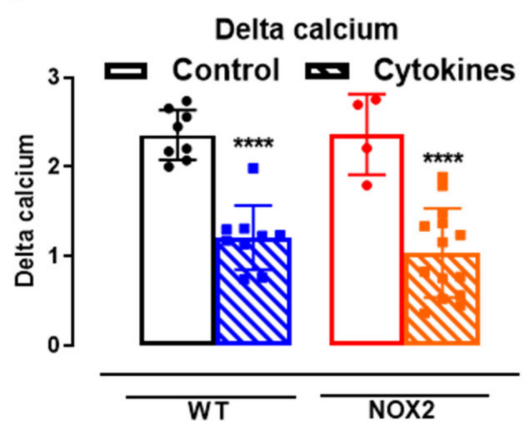

E

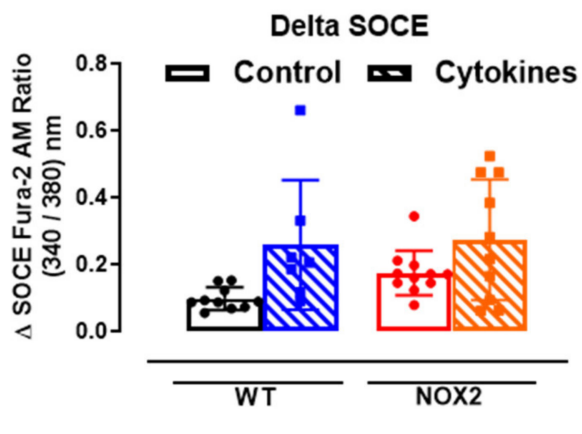

Figure 5. $\mathrm{Ca}^{2+}$ homeostasis of the islets from C57BL/6J (WT) and NOX2 KO (NOX2) mice exposed to proinflammatory cytokines. (A) Dynamic measurements of the total $\mathrm{Ca}^{2+}$ of islets from WT and NOX2 mice incubated for $24 \mathrm{~h}$ in $10-\mathrm{mM}$ glucose in the absence (Control) or presence of a proinflammatory cytokine mix (10-U/mL IL-1 $\beta+100-\mathrm{U} / \mathrm{mL}$ TNF $+14-\mathrm{U} / \mathrm{mL}$ IFN- $\gamma$ ). After incubation, the $\mathrm{Ca}^{2+}$ measurements were performed using Fura-2 AM dye under the microscope Axio Observer 7 for $5 \mathrm{~min}$ without glucose (G0) and up to $20 \mathrm{~min}$ with 20-mM glucose (G20). The dashed vertical line represents the addition of glucose. (B) Resting calcium, before the addition of glucose. (C) Delta, representing the response to glucose. The delta was calculated by $\Delta=$ mean $_{11 \text { min }}-$ mean $_{7.5 \mathrm{~min}}$ in each group. The results are expressed as the mean $\pm \mathrm{SD}$ of 4-15 individual islets (from 3 to 4 different animals per genotype). (D) Dynamic measurements of the Store-Operated Ca ${ }^{2+}$ Entry (SOCE) mechanism of islets from WT and NOX2 mice incubated for $24 \mathrm{~h}$ in 10-mM glucose in the absence (Control) or presence of a proinflammatory cytokine mix $(10-\mathrm{U} / \mathrm{mL} \mathrm{IL}-1 \beta+100-\mathrm{U} / \mathrm{mL} \mathrm{TNF}+14-\mathrm{U} / \mathrm{mL}$ IFN- $\gamma)$. After incubation, $\mathrm{Ca}^{2+}$ measurements were performed using Fura-2 AM dye under the microscope Axio Observer 7 in three steps: (1) in glucose-free and calcium-free medium (0-mM glu/0-mM Ca $\left.{ }^{2+}\right)$; followed by (2) the addition of 3- $\mu \mathrm{M}$ thapsigargin (TG, first arrow), then followed by (3) the addition of 3- $\mu \mathrm{M}$ thapsigargin and 2-mM calcium-supplemented medium (0-mM glu / 2-mM $\mathrm{Ca}^{2+}$, second arrow). (E) $\triangle \mathrm{SOCE}$ as indicated in (D). The results are expressed as the mean \pm SD of 7-14 individual islets (from 3 different animals per genotype). ${ }^{* * * *} p<0.0001$ versus the respective control at the same genotypes. One-way ANOVA + Tukey's.

3.5. NOX2 Knockout Does Not Prevent Cytokine-Induced ER Stress, but ER Stress Attenuation Prevents Cytokine-Induced Cytosolic ROS

Disturbances of the ER $\mathrm{Ca}^{2+}$ stores are directly linked to ER stress. Indeed, several articles in the literature also show that pancreatic $\beta$-cells exposed to cytokines activate the unfolded protein response (UPR) and, depending on the exposure time and concentration of the cytokines, ultimately, ER stress. Therefore, to understand whether NOX2-dependent $\mathrm{H}_{2} \mathrm{O}_{2}$ production is involved in this pathway, the expression of two important UPR proteins, namely p-eIF2 $\alpha$ and p-IRE1, was evaluated in WT and NOX2 KO islets exposed to cytokines. The islets were exposed for $4 \mathrm{~h}$ and $30 \mathrm{~min}, 6 \mathrm{~h}$ and $8 \mathrm{~h}$-time points corresponding, respectively, to the maximum peak, tail end of the peak and after the peak of cytokineinduced cytosolic $\mathrm{H}_{2} \mathrm{O}_{2}$ production (Figure 1B).

A similar increase of both the ER stress markers was observed in WT and NOX2 KO islets exposed to cytokines (Figure $6 \mathrm{~A}-\mathrm{C}$ ), indicating that the deletion of NOX2 has no 
impact on ER stress activation. Remarkably, these markers were already activated at the time point of $4 \mathrm{~h}$ and $30 \mathrm{~min}$, suggesting that cytokine-induced ER stress precedes the cytokine-induced $\mathrm{H}_{2} \mathrm{O}_{2}$ peak.

A

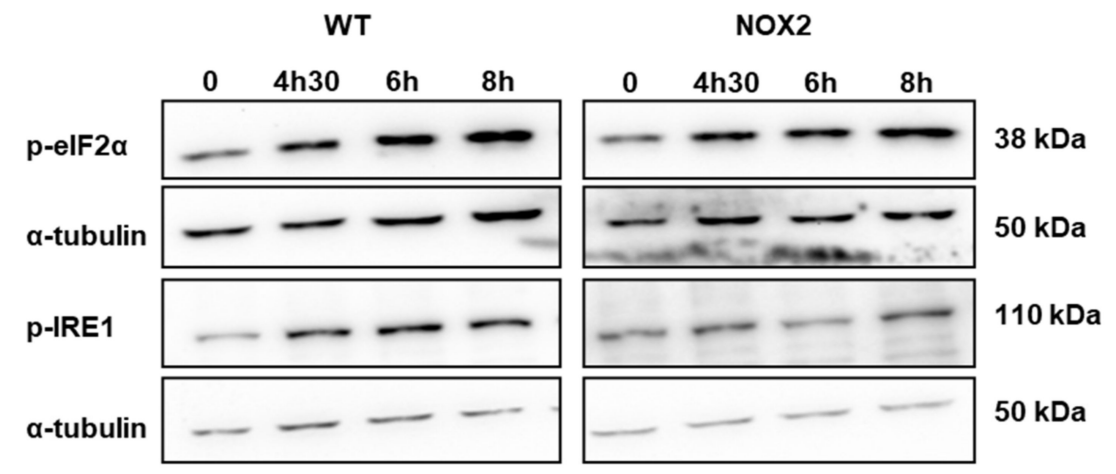

B

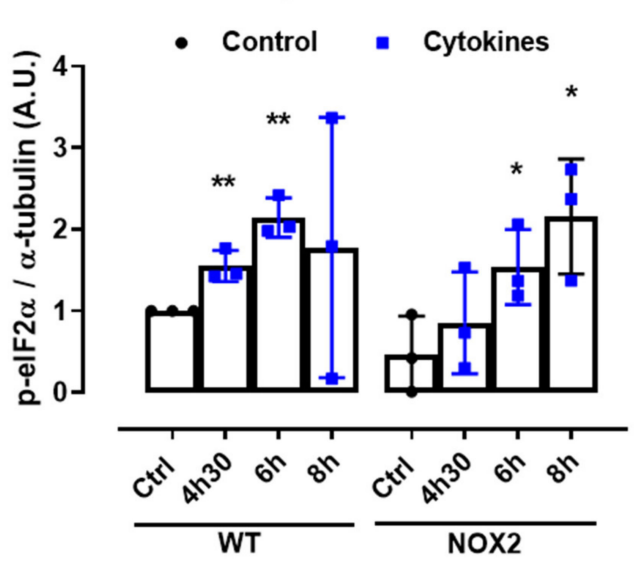

D

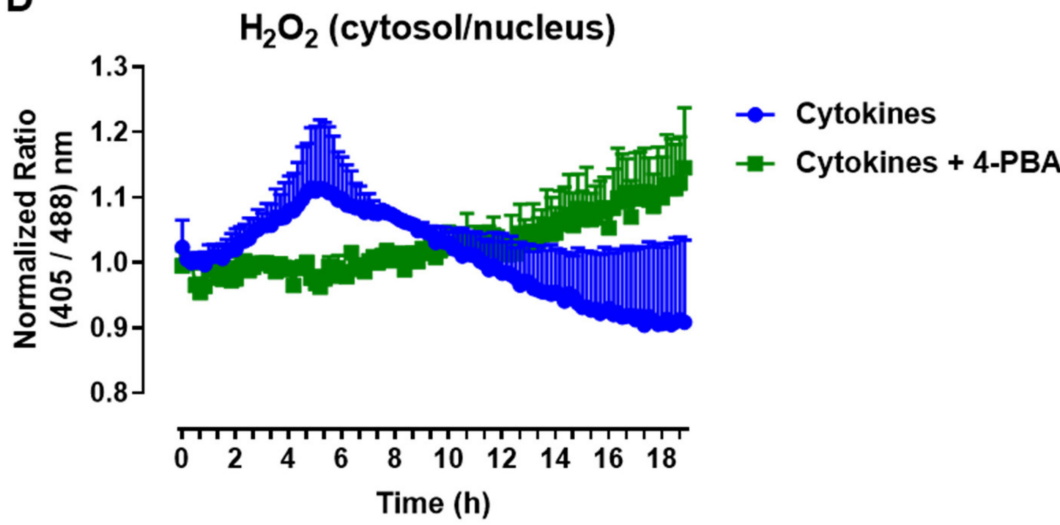

- Control - Cytokines

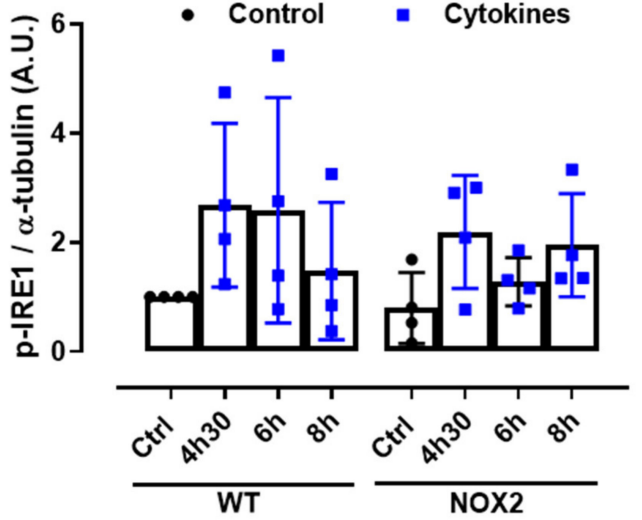

Figure 6. The protein expression of ER stress markers in the islets from C57BL/6J (WT) and NOX2 KO (NOX2) mice exposed to proinflammatory cytokines. The islets were incubated in the absence (Ctrl) or presence of a proinflammatory cytokine mix $(10-\mathrm{U} / \mathrm{mL}$ IL-1 $\beta+100-\mathrm{U} / \mathrm{mL}$ TNF $+14-\mathrm{U} / \mathrm{mL}$ IFN- $\gamma)$ for the indicated periods. A Western blot analysis was performed for p-eIF2 $\alpha$ and p-IRE1 using $\alpha$-tubulin as the internal control. (A) Representative bands and the respective $\alpha$-tubulin. (B,C) A densitometric analysis of the Western blot: p-eIF2 $\alpha$ (B) and p-IRE1 (C). The results are expressed as the mean \pm SD of 3 to 4 independent experiments. ${ }^{*} p<0.05$ and ${ }^{* *} p<0.01$ versus the respective control of the same genotype. Student's $t$-test. (D) Dynamic levels of cytosolic/nuclear $\mathrm{H}_{2} \mathrm{O}_{2}$ in the islets from roGFP2-Orp1 mice incubated with proinflammatory cytokines in the absence or presence of the ER stress chaperone 4-PBA at $2.5 \mathrm{mM}$. The fluorescence intensity was captured every $10 \mathrm{~min}$ for $18 \mathrm{~h}$. The results are presented as the normalized ratio $(405 / 488 \mathrm{~nm})$ and mean $\pm \mathrm{SD}$ of 3 independent experiments. 
To investigate this possibility, we incubated roGFP2-Orp1 islets with either cytokines alone or simultaneously with a chemical chaperone, 4-PBA, previously shown to attenuate ER stress in islets under several conditions [34,35]. The addition of 4-PBA prevented a cytokine-induced cytosolic $\mathrm{H}_{2} \mathrm{O}_{2}$ peak at earlier time points (Figure 6D), indicating that alleviating ER stress prevents $\mathrm{H}_{2} \mathrm{O}_{2}$ production and that ER stress might be an upstream event relative to NOX2-derived $\mathrm{H}_{2} \mathrm{O}_{2}$ upon cytokine exposure.

\section{Discussion}

ROS have been associated with proinflammatory cytokine-induced $\beta$-cell dysfunction and death in the context of T1D [36-38]. Here, we show that, in pancreatic islets, proinflammatory cytokines induce an increased $\mathrm{O}_{2}{ }^{-}$production and, consequently, a transient increase of the cytosolic/nuclear $\mathrm{H}_{2} \mathrm{O}_{2}$ levels, which are NOX2-dependent. We also show the role of NOX2 as a negative regulator of insulin secretion and viability upon cytokine exposure at later time points. Finally, we show that the inhibition of NOX2 does not affect cytokine-induced ER stress, and, conversely, cytokine-induced NOX2-derived ROS seems to be modulated by ER stress.

ROS are the key regulators of GSIS [13,14,39]. However, proinflammatory cytokines can exacerbate the ROS production in $\beta$-cells, overwhelming antioxidant defenses and leading to decreased insulin gene expression, the impairment of insulin secretion and cell death [14]. Given the importance of ROS as signaling molecules for $\beta$-cell functions and for their demise in T1D, for therapeutic purposes, the modulation of specific sources of ROS should be prioritized over attempts in ablating ROS production altogether.

To design these therapies, it is important to better understand the regulation of ROS production regarding its localization, source and timeframe. Various studies in pancreatic islets or $\beta$-cell lines have shown conflicting results regarding the proinflammatory cytokine modulation of different types of ROS production [6,7,40-42]. Although such differences may be influenced by the use of different models, other factors might contribute to the discrepancies among these studies, such as the employment of static methods for the evaluation of ROS based on endpoint measurements and the use of nonspecific redoxsensitive dyes, making it difficult to identify the specific sources and compartments of ROS production at a given moment.

To overcome these problems, we employed a novel strategy to assess the real-time modifications of the $\mathrm{H}_{2} \mathrm{O}_{2}$ levels in different compartments with a specific sensor [43]. We first evaluated the $\mathrm{O}_{2}{ }^{-}$production after exposure of the pancreatic islets to cytokines, and as $\mathrm{O}_{2}{ }^{--}$is rapidly converted into $\mathrm{H}_{2} \mathrm{O}_{2}$ by superoxide dismutase (SOD) [44], we also measured the $\mathrm{H}_{2} \mathrm{O}_{2}$ levels. The chronological patterns of $\mathrm{O}_{2}{ }^{\bullet-}$ and $\mathrm{H}_{2} \mathrm{O}_{2}$ production were compatible, as $\mathrm{O}_{2}{ }^{\bullet-}$ increased after $\sim 2 \mathrm{~h}$ and $\mathrm{H}_{2} \mathrm{O}_{2}$ after $\sim 4 \mathrm{~h}$ of cytokine exposure. Additionally, we were able to establish the pivotal role of the cytosol/nucleus, and not the mitochondrial matrix, as the main source of the transitory increase of ROS in $\beta$-cells exposed to proinflammatory cytokines. This is of great importance, since ROS are generally shortlived species [45] and, thus, must be relevant mainly in places close to their production.

Concomitant to the increased cytosolic $\mathrm{H}_{2} \mathrm{O}_{2}$, there was a decrease of the $\mathrm{NAD}(\mathrm{P}) \mathrm{H}$ levels. A primary mechanism by which $\mathrm{H}_{2} \mathrm{O}_{2}$ exerts its effects is via selective protein thiol oxidation, which is antagonized by reductive systems dependent on $\mathrm{NAD}(\mathrm{P}) \mathrm{H}$ [46]. Thus, we speculate whether the $\mathrm{NAD}(\mathrm{P}) \mathrm{H}$ decrease is related to its consumption by reductive enzymes, such as glutaredoxins, thioredoxins and peroxiredoxins, and whether it might be responsible for the subsequent decrease in $\mathrm{H}_{2} \mathrm{O}_{2}$. This would be interesting to be evaluated in future studies. Importantly, peroxiredoxins have been shown to participate in innumerous redox relays [47], which allow the transfer of oxidation to several target proteins and transcription factors [48-50]. This mechanism allows cells to specifically modulate signaling upon ROS production, even if this production is short-lived.

The observed cytokine-induced $\mathrm{H}_{2} \mathrm{O}_{2}$ increase mainly in the cytosol was indicative of the participation of the NOX enzyme, which is an important cytosolic source of $\mathrm{O}_{2}{ }^{--}$. Consistent with this, previous studies showed that cytokine-induced increased ROS production 
was prevented in several $\beta$-cell models by means of different NOX inhibitors [36-38,42]. However, the use of inhibitors with variable specificities to several NOX isoforms casts significant doubt regarding the specific pathophysiological role of each isoform [51,52]. Here, we used NOX1 KO and NOX2 KO islets, and our results indicated the specific involvement of NOX2, since, only in NOX2 $\mathrm{KO}$ islets, the production of $\mathrm{O}_{2}{ }^{\bullet-}$ in response to cytokines was completely abolished. In addition, we confirmed NOX2 involvement in the $\mathrm{H}_{2} \mathrm{O}_{2}$ real-time increase using both pharmacological inhibition and deletion by knockout. Our results indicated NOX 2 as a potential target for protecting $\beta$-cells from oxidative stress during insulitis.

Previous studies have shown $\beta$-cell protection against the cytokine-induced impairment of the secretory capacity by the use of a NOX1/4 inhibitor [37] or NOX2 KO islets [38]. Moreover, the absence of NOX2 protected mice from $\beta$-cell demise and T1D development in a streptozotocin-induced T1D model [38]. Our results showed that NOX2 KO, and not NOX1 KO, mice were more glucose tolerant, and their isolated islets were partially protected against the cytokine-induced impairment of insulin secretion. Thus, the absence of NOX2 is beneficial for $\beta$-cell function both in vivo and in vitro. Particularly, our results showed that early cytokine-induced NOX2-derived ROS production impacts $\beta$-cell function.

A glucose-induced $\mathrm{Ca}^{2+}$ influx is the main trigger for insulin exocytosis [53,54]. Exposure to proinflammatory cytokines is known to induce perturbations in $\mathrm{Ca}^{2+}$ homeostasis in $\beta$-cells [33]. We showed that, although the absence of NOX2 was beneficial for the secretory function of islets exposed to cytokines, it did not impact the cytokine-induced dysfunction of the glucose-dependent $\mathrm{Ca}^{2+}$ response. This finding was surprising, since we observed a better secretory profile of the NOX2 KO islets. This indicates that $\mathrm{Ca}^{2+}$-independent mechanisms [55-57] may be involved in the maintenance of insulin secretion in NOX2 KO islets exposed to cytokines.

$\mathrm{A} \mathrm{Ca}^{2+}$ influx is crucial for GSIS, but its greater relevance appears to occur in the first phase (triggering pathway), while the second phase (amplifying pathway)—responsible for increasing the magnitude of the secretory response-may be independent of both the $\mathrm{K}_{\mathrm{ATP}}$ and $\mathrm{Ca}^{2+}$ influx [55]. Although the underlying mechanisms are not entirely clear, they might involve glucose metabolism and metabolic coupling factors, such as NADPH, cyclic AMP, GTP, malonyl-CoA, long-chain acyl-CoA and glutamate [58,59]. Indeed, NOX2 ablation has been previously shown to increase insulin secretion, with no major impact in the $\mathrm{Ca}^{2+}$ influx and metabolism [22,60], suggesting a modulatory action at distal steps on the insulin secretion process. One of the possible targets of NOX2 could be the exocytotic machinery, which has several proteins that are redox-sensitive, such as the N-ethylmaleimide-sensitive factor (NSF) [61] and SNAP25 [62]. Therefore, it is tempting to speculate that NOX2 deletion and, consequently, decreased $\mathrm{H}_{2} \mathrm{O}_{2}$ production may control insulin exocytosis by oxidizing thiol groups in exocytotic proteins, acting at the last step of insulin secretion. ROS have been previously suggested as stimulators of insulin secretion; however, their specific role probably depends on the stimulus, amount, source and intracellular targets $[63,64]$.

Previous studies have focused special attention on NADPH as crucial for GSIS amplification [65-67]. For instance, the intracellular addition of NADPH into $\beta$-cells enhanced insulin exocytosis [65]. The precise mechanisms involved are not completely understood but might involve the NADPH-dependent activation of sentrin/SUMO-specific protease-1 (SENP1), involved in the amplification of insulin exocytosis $[67,68]$. Thus, in WT islets exposed to cytokines, the NOX2-derived ROS and the consequent NAD $(\mathrm{P}) \mathrm{H}$ depletion observed here might play a role in the secretory impairment. It is also plausible that cytokine-treated $\mathrm{KO}$ islets preserve their secretory capacity due to the absence of NOX2derived ROS and, therefore, preserve cytosolic NADPH at sufficient levels to maintain a GSIS amplification. In addition, NOX2 mediates the electron transfer to $\mathrm{O}_{2}$ to produce $\mathrm{O}_{2}{ }^{\bullet-}$ using NADPH as the electron donor [11,12]. 
The main $\mathrm{Ca}^{2+}$ storage compartment in mammalian cells is the ER, and several studies have shown that conditions mimicking diabetes, such as $\beta$-cell exposure to palmitic acid or cytokines, lead to the depletion of $\mathrm{ER} \mathrm{Ca}^{2+}[3,26,69,70]$. The consequence of this depletion is the induction of ER stress, leading to $\beta$-cell dysfunction and death. It has been recently shown that, after ER $\mathrm{Ca}^{2+}$ depletion, the SOCE mechanism is activated to replenish the ER $\mathrm{Ca}^{2+}$ stores through the induction of extracellular $\mathrm{Ca}^{2+}$ entry $[25,71]$. Thus, we investigated whether the absence of NOX2 rendered islet cells more sensitive to cytokine-induced impairment in the SOCE mechanism and activation of ER stress. Despite, as expected, cytokines leading to alterations in the SOCE and increasing the activation of ER stress markers in WT islets, the absence of NOX2 had no significant effect on these phenomena. Further experiments are needed to completely exclude the involvement of NOX-derived ROS in cytokine-induced ER stress. However, it is known that this process is strongly related to nitric oxide (NO) production [26,72], and thus, other reactive species, such as $\mathrm{NO}$, could play a major role here.

Notably, the phosphorylation of two important UPR proteins (p-eIF2- $\alpha$ and p-IRE1) were already increased at $4 \mathrm{~h}$ and $30 \mathrm{~min}$, suggesting an earlier activation. This activation precedes the $\mathrm{H}_{2} \mathrm{O}_{2}$ production by NOX2, as seen by our plate reader measurements. A possible mechanistic explanation is that the UPR is activated prior to NOX2 or even that it is responsible for NOX2 activation, as shown in other cell types [73-75]. Of note, it has been previously shown that the same UPR branch is induced earlier than $4 \mathrm{~h}$ and $30 \mathrm{~min}$ by cytokines in $\beta$-cells after only $2 \mathrm{~h}$ of exposure and is involved in $\beta$-cell death under these conditions $[76,77]$. Supporting this idea, we observed here that using a chemical chaperone to attenuate ER stress delays the cytokine-induced cytosolic $\mathrm{H}_{2} \mathrm{O}_{2}$ peak. The precise mechanistic details and hierarchy of these pathways is not known. However, the ER stress attenuation with 4-PBA has been shown to protect $\beta$-cell functions and/or survival in several conditions, including palmitate exposure and inflammatory insult $[78,79]$. We suggest that this crosstalk between ER stress and, subsequently, NOX2-derived $\mathrm{H}_{2} \mathrm{O}_{2}$ production at a specific and early time point is closely related to the $\beta$-cell dysfunction and death in later time points. This possibility would be extremely interesting to follow up in future studies and could explain some similarities in the cytosolic ROS response between cytokine and palmitate treatments [23], as both activate UPR and ER stress, which can then converge in NOX2 activation.

\section{Conclusions}

We provide evidence that cytokine-induced NOX2-dependent transient cytosolic $\mathrm{H}_{2} \mathrm{O}_{2}$ production has a great impact on $\beta$-cell function and survival, without affecting the $\mathrm{Ca}^{2+}$ dynamics and ER stress activation, which might be upstream of the NOX2 activation. This highlights the importance of better understanding the dynamics involved in ROS production by different sources as an extremely delicate system. We believe that this is the first step towards designing more effective therapies focusing on NOX2 modulation, which could benefit $\beta$-cell preservation in the context of T1D onset.

Supplementary Materials: The following are available online at https:/ / www.mdpi.com/article/1 0.3390 /antiox10081305/s1, Figure S1: Dynamic levels of cytosolic/nuclear or mitochondrial $\mathrm{H}_{2} \mathrm{O}_{2}$ in islets exposed to different combinations of proinflammatory cytokines.

Author Contributions: Conceptualization, E.A.V.-B., A.R.C., L.P.R. and F.O.; methodology, E.A.V.-B., L.P.R. and F.O.; formal analysis, E.A.V.-B., L.P.R. and F.O.; investigation, E.A.V.-B., C.C., L.N., D.C.A. and E.A.; resources, A.R.C., L.P.R. and F.O.; writing-original draft preparation, E.A.V.-B., L.P.R. and F.O.; writing-review and editing, E.A.V.-B., C.C., D.C.A., L.P.R. and F.O.; visualization, E.A.V.-B., L.P.R. and F.O.; supervision, A.R.C., L.P.R. and F.O.; project administration, E.A.V.-B. and funding acquisition, E.A.V.-B., A.R.C., L.P.R. and F.O. All authors have read and agreed to the published version of the manuscript.

Funding: L.P.R. was supported by the Deutsche Forschungsgemeinschaft in the context of SFB894 (project A13) and TRR219, Project ID 322900939. F.O. and A.R.C. were supported by Fundação 
de Amparo à Pesquisa do Estado de São Paulo (FAPESP) under grant numbers 2017/04580-2, 2013/08769-1, 2017/26339-5 and 2020/06184-0. E.A.V.-B. was supported by Conselho Nacional de Desenvolvimento Científico e Tecnológico (CNPq) under grant number 142008/2016-8 by the EFSD Albert Renold Travel Fellowship Programme 2019 and by GradUS Global funding DAAD 2018.

Institutional Review Board Statement: This study was conducted according to the guidelines of the local ethical committees and was approved by the Ethics Committee on the Use of Animals of the Institute of Biomedical Sciences of the University of Sao Paulo (CEUA-ICB/USP, Process $n$. 62/2016/CEUA) and Saarland University, Germany.

Informed Consent Statement: Not applicable.

Data Availability Statement: Data is contained within the article and Supplementary Material.

Acknowledgments: The authors thank Marlene Santos da Rocha (Department of Physiology and Biophysics, Institute of Biomedical Sciences, University of Sao Paulo, Brazil), Adriane Pereira Fernandes Araujo (Department of Cell and Developmental Biology, Institute of Biomedical Sciences, University of Sao Paulo, Brazil), Andrea Armbrüster and Sandra Janku (Department of Biophysics, Center for Human and Molecular Biology (ZHMB), Saarland University, Homburg, Germany) and Caroline Bickelmann (Institute for Clinical and Experimental Surgery, Saarland University, Homburg, Germany) for their excellent technical assistance.

Conflicts of Interest: The authors declare no conflict of interest. The funders had no role in the design of the study; in the collection, analyses or interpretation of the data; in the writing of the manuscript or in the decision to publish the results.

\section{References}

1. Atkinson, M.A.; Eisenbarth, G.S.; Michels, A.W. Type 1 diabetes. Lancet 2014, 383, 69-82. [CrossRef]

2. Cnop, M.; Welsh, N.; Jonas, J.C.; Jörns, A.; Lenzen, S.; Eizirik, D.L. Mechanisms of pancreatic beta-cell death in type 1 and type 2 diabetes: Many differences, few similarities. Diabetes 2005, 54, S97-S107. [CrossRef] [PubMed]

3. Eizirik, D.L.; Colli, M.L.; Ortis, F. The role of inflammation in insulitis and $\beta$-cell loss in type 1 diabetes. Nat. Rev. Endocrinol. 2009, 5, 219-226. [CrossRef] [PubMed]

4. Wilcox, N.S.; Rui, J.; Hebrok, M.; Herold, K.C. Life and death of $\beta$ cells in Type 1 diabetes: A comprehensive review. J. Autoimmun. 2016, 71, 51-58. [CrossRef] [PubMed]

5. Eizirik, D.L.; Mandrup-Poulsen, T. A choice of death-The signal-transduction of immune-mediated beta-cell apoptosis. Diabetologia 2001, 44, 2115-2133. [CrossRef]

6. Rabinovitch, A.; Suarez-Pinzon, W.L.; Strynadka, K.; Lakey, J.R.; Rajotte, R.V. Human pancreatic islet beta-cell destruction by cytokines involves oxygen free radicals and aldehyde production. J. Clin. Endocrinol. Metab. 1996, 81, 3197-3202. [CrossRef]

7. Lakey, J.R.; Suarez-Pinzon, W.L.; Strynadka, K.; Korbutt, G.S.; Rajotte, R.V.; Mabley, J.G.; Szabó, C.; Rabinovitch, A. Peroxynitrite is a mediator of cytokine-induced destruction of human pancreatic islet beta cells. Lab. Investig. 2001, 81, 1683-1692. [CrossRef]

8. Lenzen, S. Oxidative stress: The vulnerable $\beta$-cell. Biochem. Soc. Trans. 2008, 36, 343-347. [CrossRef]

9. Oliveira, H.R.; Verlengia, R.; Carvalho, C.R.; Britto, L.R.; Curi, R.; Carpinelli, A.R. Pancreatic beta-cells express phagocyte-like NAD(P)H oxidase. Diabetes 2003, 52, 1457-1463. [CrossRef]

10. Rebelato, E.; Mares-Guia, T.; Graciano, M.F.R.; Labriola, L.; Britto, L.R.; Garay-Malpartida, H.M.; Curi, R.; Sogayar, M.; Carpinelli, A. Expression of NADPH oxidase in human pancreatic islets. Life Sci. 2012, 91, 244-249. [CrossRef]

11. Buvelot, H.; Jaquet, V.; Krause, K.-H. Mammalian NADPH Oxidases. Methods Mol. Biol. 2019, 1982, 17-36. [PubMed]

12. Bedard, K.; Krause, K.H. The NOX Family of ROS-Generating NADPH Oxidases: Physiology and Pathophysiology. Physiol. Rev. 2007, 87, 245-313. [CrossRef] [PubMed]

13. Morgan, D.; Rebelato, E.; Abdulkader, F.; Graciano, M.F.R.; Oliveira-Emilio, H.R.; Hirata, A.E.; Rocha, M.S.; Bordin, S.; Curi, R.; Carpinelli, A. Association of NAD(P)H Oxidase with Glucose-Induced Insulin Secretion by Pancreatic $\beta$-Cells. Endocrinology 2009, 150, 2197-2201. [CrossRef]

14. Pi, J.; Bai, Y.; Zhang, Q.; Wong, V.; Floering, L.M.; Daniel, K.; Reece, J.M.; Deeney, J.; Andersen, M.; Corkey, B.; et al. Reactive Oxygen Species as a Signal in Glucose-Stimulated Insulin Secretion. Diabetes 2007, 56, 1783-1791. [CrossRef]

15. Kowluru, A. Friendly, and not so friendly, roles of Rac1 in islet $\beta$-cell function: Lessons learnt from pharmacological and molecular biological approaches. Biochem. Pharmacol. 2011, 81, 965-975. [CrossRef] [PubMed]

16. Winterbourn, C.C. Reconciling the chemistry and biology of reactive oxygen species. Nat. Chem. Biol. 2008, 4, 278-286. [CrossRef]

17. Fujikawa, Y.; Roma, L.P.; Sobotta, M.C.; Rose, A.J.; Diaz, M.B.; Locatelli, G.; Breckwoldt, M.O.; Misgeld, T.; Kerschensteiner, M.; Herzig, S.; et al. Mouse redox histology using genetically encoded probes. Sci. Signal 2016, 9, rs1. [CrossRef]

18. Deglasse, J.-P.; Roma, L.P.; Pastor-Flores, D.; Gilon, P.; Dick, T.P.; Jonas, J.-C. Glucose Acutely Reduces Cytosolic and Mitochondrial $\mathrm{H}_{2} \mathrm{O}_{2}$ in Rat Pancreatic Beta Cells. Antioxid. Redox Signal. 2019, 30, 297-313. [CrossRef] [PubMed] 
19. Lortz, S.; Gurgul-Convey, E.; Naujok, O.; Lenzen, S. Overexpression of the antioxidant enzyme catalase does not interfere with the glucose responsiveness of insulin-secreting INS-1E cells and rat islets. Diabetologia 2013, 56, 774-782. [CrossRef]

20. Ortis, F.; Cardozo, A.K.; Crispim, D.; Störling, J.; Mandrup-Poulsen, T.; Eizirik, D.L. Cytokine-Induced Proapoptotic Gene Expression in Insulin-Producing Cells Is Related to Rapid, Sustained, and Nonoscillatory Nuclear Factor- $\mathrm{kB}$ Activation. Mol. Endocrinol. 2006, 20, 1867-1879. [CrossRef]

21. Hirano, K.; Chen, W.S.; Chueng, A.L.; Dunne, A.A.; Seredenina, T.; Filippova, A.; Ramachandran, S.; Bridges, A.; Chaudry, L.; Pettman, G.; et al. Discovery of GSK2795039, a Novel Small Molecule NADPH Oxidase 2 Inhibitor. Antioxid. Redox Signal. 2015, 23, 358-374. [CrossRef]

22. de Souza, A.H.; Santos, L.R.; Roma, L.P.; Bensellam, M.; Carpinelli, A.R.; Jonas, J.-C. NADPH oxidase-2 does not contribute to $\beta$-cell glucotoxicity in cultured pancreatic islets from C57BL/6J mice. Mol. Cell. Endocrinol. 2017, 439, 354-362. [CrossRef]

23. Vilas-Boas, E.A.; Nalbach, L.; Ampofo, E.; Lucena, C.F.; Naudet, L.; Ortis, F.; Carpinelli, A.R.; Morgan, B.; Roma, L.P. Transient NADPH oxidase 2-dependent $\mathrm{H}_{2} \mathrm{O}_{2}$ production drives early palmitate-induced lipotoxicity in pancreatic islets. Free Radic. Biol. Med. 2021, 162, 1-13. [CrossRef]

24. Munhoz, A.C.; Vilas-Boas, E.A.; Panveloski-Costa, A.C.; Leite, J.S.M.; Lucena, C.F.; Riva, P.; Emilio, H.; Carpinelli, A.R. Intermittent Fasting for Twelve Weeks Leads to Increases in Fat Mass and Hyperinsulinemia in Young Female Wistar Rats. Nutrients 2020, 12, 1029. [CrossRef] [PubMed]

25. Kono, T.; Tong, X.; Taleb, S.; Bone, R.N.; Iida, H.; Lee, C.-C.; Sohn, P.; Gilon, P.; Roe, M.W.; Evans-Molina, C. Impaired StoreOperated Calcium Entry and STIM1 Loss Lead to Reduced Insulin Secretion and Increased Endoplasmic Reticulum Stress in the Diabetic $\beta$-Cell. Diabetes 2018, 67, 2293-2304. [CrossRef]

26. Brozzi, F.; Eizirik, D.L. ER stress and the decline and fall of pancreatic beta cells in type 1 diabetes. Upsala J. Med. Sci. 2016, 121, 133-139. [CrossRef]

27. Vilas-Boas, E.A.; Karabacz, N.; Marsiglio-Librais, G.N.; Valle, M.M.R.; Nalbach, L.; Ampofo, E.; Morgan, B.; Carpinelli, A.R.; Roma, L.P. Chronic activation of GPR40 does not negatively impact upon BRIN-BD11 pancreatic $\beta$-cell physiology and function. Pharmacol. Rep. 2020, 72, 1725-1737. [CrossRef] [PubMed]

28. Takahashi, H.K.; Santos, L.R.B.; Roma, L.P.; Duprez, J.; Broca, C.; Wojtusciszyn, A.; Jonas, J. Acute nutrient regulation of the mitochondrial glutathione redox state in pancreatic $\beta$-cells. Biochem. J. 2014, 460, 411-423. [CrossRef] [PubMed]

29. Nalbach, L.; Roma, L.P.; Schmitt, B.M.; Becker, V.; Körbel, C.; Wrublewsky, S.; Pack, M.; Später, T.; Metzger, W.; Menger, M.M.; et al. Improvement of islet transplantation by the fusion of islet cells with functional blood vessels. EMBO Mol. Med. 2021, 13 , e12616. [CrossRef] [PubMed]

30. Swain, L.; Nanadikar, M.S.; Borowik, S.; Zieseniss, A.; Katschinski, D.M. Transgenic Organisms Meet Redox Bioimaging: One Step Closer to Physiology. Antioxid. Redox Signal. 2018, 29, 603-612. [CrossRef]

31. Swain, L.; Kesemeyer, A.; Meyer-Roxlau, S.; Vettel, C.; Zieseniss, A.; Güntsch, A.; Jatho, A.; Becker, A.; Nanadikar, M.S.; Morgan, B.; et al. Redox Imaging Using Cardiac Myocyte-Specific Transgenic Biosensor Mice. Circ. Res. 2016, 119, 1004-1016. [CrossRef]

32. Zou, H.; Yang, W.; Schwär, G.; Zhao, R.; AlAnsary, D.; Yin, D.; Schwarz, E.C.; Niemeyer, B.A.; Qu, B. High glucose distinctively regulates $\mathrm{Ca}^{2+}$ influx in cytotoxic T lymphocytes upon target recognition and thapsigargin stimulation. Eur. J. Immunol. 2020, 50, 2095-2098. [CrossRef]

33. Ramadan, J.W.; Steiner, S.R.; O'Neill, C.M.; Nunemaker, C.S. The central role of calcium in the effects of cytokines on beta-cell function: Implications for type 1 and type 2 diabetes. Cell Calcium 2011, 50, 481-490. [CrossRef] [PubMed]

34. Hong, Y.-P.; Guo, W.-Y.; Wang, W.-X.; Zhao, L.; Xiang, M.-W.; Mei, F.-C.; Abliz, A.; Hu, P.; Deng, W.-H.; Yu, J. 4-Phenylbutyric Acid Attenuates Pancreatic Beta-Cell Injury in Rats with Experimental Severe Acute Pancreatitis. Int. J. Endocrinol. 2016, 2016, 1-11. [CrossRef] [PubMed]

35. Zhou, X.; Xu, Y.; Gu, Y.; Sun, M. 4-Phenylbutyric acid protects islet $\beta$ cell against cellular damage induced by glucocorticoids. Mol. Biol. Rep. 2021, 48, 1659-1665. [CrossRef]

36. Subasinghe, W.; Syed, I.; Kowluru, A. Phagocyte-like NADPH oxidase promotes cytokine-induced mitochondrial dysfunction in pancreatic $\beta$-cells: Evidence for regulation by Rac1. Am. J. Physiol. Integr. Comp. Physiol. 2011, 300, R12-R20. [CrossRef] [PubMed]

37. Weaver, J.R.; Grzesik, W.; Taylor-Fishwick, D.A. Inhibition of NADPH oxidase-1 preserves beta cell function. Diabetologia 2014, 58, 113-121. [CrossRef] [PubMed]

38. Xiang, F.-L.; Lu, X.; Strutt, B.; Hill, D.J.; Feng, Q. NOX2 Deficiency Protects Against Streptozotocin-Induced $\beta$-Cell Destruction and Development of Diabetes in Mice. Diabetes 2010, 59, 2603-2611. [CrossRef] [PubMed]

39. Munhoz, A.C.; Riva, P.; Simões, D.; Curi, R.; Carpinelli, A. Control of Insulin Secretion by Production of Reactive Oxygen Species: Study Performed in Pancreatic Islets from Fed and 48-Hour Fasted Wistar Rats. PLoS ONE 2016, 11, e0158166. [CrossRef] [PubMed]

40. Barbu, A.; Welsh, N.; Saldeen, J. Cytokine-induced apoptosis and necrosis are preceded by disruption of the mitochondrial membrane potential $(\Delta \psi \mathrm{m})$ in pancreatic RINm5F cells: Prevention by Bcl-2. Mol. Cell. Endocrinol. 2002, 190, 75-82. [CrossRef]

41. Kim, W.H.; Lee, J.W.; Gao, B.; Jung, M.H. Synergistic activation of JNK/SAPK induced by TNF- $\alpha$ and IFN- $\gamma$ : Apoptosis of pancreatic $\beta$-cells via the p53 and ROS pathway. Cell. Signal. 2005, 17, 1516-1532. [CrossRef] 
42. Morgan, D.; Oliveira-Emilio, H.R.; Keane, D.; Hirata, A.E.; Da Rocha, M.S.; Bordin, S.; Curi, R.; Newsholme, P.; Carpinelli, A.R. Glucose, palmitate and pro-inflammatory cytokines modulate production and activity of a phagocyte-like NADPH oxidase in rat pancreatic islets and a clonal beta cell line. Diabetologia 2007, 50, 359-369. [CrossRef]

43. Morgan, B.; Sobotta, M.C.; Dick, T.P. Measuring EGSH and H2O2 with roGFP2-based redox probes. Free Radic. Biol. Med. 2011, 51, 1943-1951. [CrossRef]

44. Fridovich, I. Superoxide Radical and Superoxide Dismutases. Annu. Rev. Biochem. 1995, 64, 97-112. [CrossRef]

45. Lenzen, S. Chemistry and biology of reactive species with special reference to the antioxidative defence status in pancreatic ß-cells. Biochim. Biophys. Acta-Gen. Subj. 2017, 1861, 1929-1942. [CrossRef]

46. Miller, C.G.; Holmgren, A.; Arnér, E.; Schmidt, E.E. NADPH-dependent and -independent disulfide reductase systems. Free. Radic. Biol. Med. 2018, 127, 248-261. [CrossRef]

47. Sobotta, M.C.; Liou, W.; Stöcker, S.; Talwar, D.; Oehler, M.; Ruppert, T.; Scharf, A.N.D.; Dick, T.P. Peroxiredoxin-2 and STAT3 form a redox relay for $\mathrm{H}_{2} \mathrm{O}_{2}$ signaling. Nat. Chem. Biol. 2015, 11, 64-70. [CrossRef] [PubMed]

48. Stancill, J.; Broniowska, K.A.; Oleson, B.J.; Naatz, A.; Corbett, J.A. Pancreatic $\beta$-cells detoxify $\mathrm{H}_{2} \mathrm{O}_{2}$ through the peroxiredoxin/thioredoxin antioxidant system. J. Biol. Chem. 2019, 294, 4843-4853. [CrossRef] [PubMed]

49. Sies, H. Hydrogen peroxide as a central redox signaling molecule in physiological oxidative stress: Oxidative eustress. Redox Biol. 2017, 11, 613-619. [CrossRef] [PubMed]

50. Sies, H.; Jones, D.P. Reactive oxygen species (ROS) as pleiotropic physiological signalling agents. Nat. Rev. Mol. Cell Biol. 2020, 21, 363-383. [CrossRef] [PubMed]

51. Altenhöfer, S.; Radermacher, K.A.; Kleikers, P.W.M.; Wingler, K.; Schmidt, H.H.H.W. Evolution of NADPH Oxidase Inhibitors: Selectivity and Mechanisms for Target Engagement. Antioxid. Redox Signal. 2015, 23, 406-427. [CrossRef] [PubMed]

52. Augsburger, F.; Filippova, A.; Rasti, D.; Seredenina, T.; Lam, M.; Maghzal, G.; Mahiout, Z.; Jansen-Dürr, P.; Knaus, U.G.; Doroshow, J.; et al. Pharmacological characterization of the seven human NOX isoforms and their inhibitors. Redox Biol. 2019, 26, 101272. [CrossRef] [PubMed]

53. Kalwat, M.A.; Cobb, M.H. Mechanisms of the amplifying pathway of insulin secretion in the $\beta$ cell. Pharmacol. Ther. 2017, 179, 17-30. [CrossRef] [PubMed]

54. Pedersen, M.G.; Tagliavini, A.; Henquin, J.-C. Calcium signaling and secretory granule pool dynamics underlie biphasic insulin secretion and its amplification by glucose: Experiments and modeling. Am. J. Physiol. Metab. 2019, 316, E475-E486. [CrossRef]

55. Henquin, J.C.; Nenquin, M.; Ravier, M.A.; Szollosi, A. Shortcomings of current models of glucose-induced insulin secretion. Diabetes Obes. Metab. 2009, 11, 168-179. [CrossRef]

56. Sakuma, N.; Ishikawa, S.-E.; Okada, K.; Miyazaki, J.-I.; Saito, T. Glucose induces calcium-dependent and calcium-independent insulin secretion from the pancreatic beta cell line MIN6. Eur. J. Endocrinol. 1995, 133, 227-234. [CrossRef]

57. Komatsu, M.; Schermerhorn, T.; Aizawa, T.; Sharp, G.W. Glucose stimulation of insulin release in the absence of extracellular Ca ${ }^{2+}$ and in the absence of any increase in intracellular $\mathrm{Ca}^{2+}$ in rat pancreatic islets. Proc. Natl. Acad. Sci. USA 1995, 92, 10728-10732. [CrossRef]

58. Maechler, P.; Wollheim, C.B. Mitochondrial signals in glucose-stimulated insulin secretion in the beta cell. J. Physiol. 2000, 529, 49-56. [CrossRef]

59. Jitrapakdee, S.; Wutthisathapornchai, A.; Wallace, J.C.; Macdonald, M.J. Regulation of insulin secretion: Role of mitochondrial signalling. Diabetologia 2010, 53, 1019-1032. [CrossRef]

60. Li, N.; Li, B.; Brun, T.; Deffert-Delbouille, C.; Mahiout, Z.; Daali, Y.; Ma, X.-J.; Krause, K.-H.; Maechler, P. NADPH Oxidase NOX2 Defines a New Antagonistic Role for Reactive Oxygen Species and cAMP/PKA in the Regulation of Insulin Secretion. Diabetes 2012, 61, 2842-2850. [CrossRef]

61. Lowenstein, C.J.; Tsuda, H. N-Ethylmaleimide-sensitive factor: A redox sensor in exocytosis. Biol. Chem. 2006, 387, 1377-1383. [CrossRef] [PubMed]

62. Giniatullin, A.; Darios, F.; Shakirzyanova, A.; Davletov, B. SNAP25 is a pre-synaptic target for the depressant action of reactive oxygen species on transmitter release. J. Neurochem. 2006, 98, 1789-1797. [CrossRef] [PubMed]

63. Leloup, C.; Tourrel-Cuzin, C.; Magnan, C.; Karaca, M.; Castel, J.; Carneiro, L.; Colombani, A.-L.; Ktorza, A.; Casteilla, L.; Penicaud, L. Mitochondrial Reactive Oxygen Species Are Obligatory Signals for Glucose-Induced Insulin Secretion. Diabetes 2009, 58, 673-681. [CrossRef] [PubMed]

64. Plecitá-Hlavatá, L.; Jaburek, M.; Holendova, B.; Tauber, J.; Pavluch, V.; Berková, Z.; Cahová, M.; Schröder, K.; Brandes, R.P.; Siemen, D.; et al. Glucose-Stimulated Insulin Secretion Fundamentally Requires $\mathrm{H}_{2} \mathrm{O}_{2}$ Signaling by NADPH Oxidase 4. Diabetes 2020, 69, 1341-1354. [CrossRef] [PubMed]

65. Ivarsson, R.; Quintens, R.; Dejonghe, S.; Tsukamoto, K.; Veld, P.I.; Renström, E.; Schuit, F.C. Redox Control of Exocytosis: Regulatory Role of NADPH, Thioredoxin, and Glutaredoxin. Diabetes 2005, 54, 2132-2142. [CrossRef] [PubMed]

66. Ronnebaum, S.; Ilkayeva, O.; Burgess, S.C.; Joseph, J.W.; Lu, D.; Stevens, R.D.; Becker, T.C.; Sherry, D.; Newgard, C.B.; Jensen, M.V. A Pyruvate Cycling Pathway Involving Cytosolic NADP-dependent Isocitrate Dehydrogenase Regulates Glucose-stimulated Insulin Secretion. J. Biol. Chem. 2006, 281, 30593-30602. [CrossRef]

67. Attie, A.D. How do reducing equivalents increase insulin secretion? J. Clin. Investig. 2015, 125, 3754-3756. [CrossRef] 
68. Ferdaoussi, M.; Dai, X.; Jensen, M.V.; Wang, R.; Peterson, B.S.; Huang, C.; Ilkayeva, O.; Smith, N.; Miller, N.; Hajmrle, C.; et al. Isocitrate-to-SENP1 signaling amplifies insulin secretion and rescues dysfunctional $\beta$ cells. J. Clin. Investig. 2015, 125, 3847-3860. [CrossRef]

69. Eizirik, D.L.; Miani, M.; Cardozo, A.K. Signalling danger: Endoplasmic reticulum stress and the unfolded protein response in pancreatic islet inflammation. Diabetologia 2013, 56, 234-241. [CrossRef]

70. Meyerovich, K.; Ortis, F.; Allagnat, F.; Cardozo, A.K. Endoplasmic reticulum stress and the unfolded protein response in pancreatic islet inflammation. J. Mol. Endocrinol. 2016, 57, R1-R17. [CrossRef]

71. Gwiazda, K.S.; Yang, T.-L.B.; Lin, Y.; Johnson, J. Effects of palmitate on ER and cytosolic Ca ${ }^{2+}$ homeostasis in $\beta$-cells. Am. J. Physiol. Metab. 2009, 296, E690-E701. [CrossRef]

72. Oyadomari, S.; Araki, E.; Mori, M. Endoplasmic reticulum stress-mediated apoptosis in pancreatic beta-cells. Apoptosis 2002, 7, 335-345. [CrossRef]

73. Li, G.; Scull, C.; Ozcan, L.; Tabas, I. NADPH oxidase links endoplasmic reticulum stress, oxidative stress, and PKR activation to induce apoptosis. J. Cell Biol. 2010, 191, 1113-1125. [CrossRef]

74. Amodio, G.; Moltedo, O.; Faraonio, R.; Remondelli, P. Targeting the Endoplasmic Reticulum Unfolded Protein Response to Counteract the Oxidative Stress-Induced Endothelial Dysfunction. Oxid. Med. Cell. Longev. 2018, 2018, 1-13. [CrossRef] [PubMed]

75. Laurindo, F.R.; Araujo, T.; Abrahão, T.B. Nox NADPH Oxidases and the Endoplasmic Reticulum. Antioxid. Redox Signal. 2014, 20, 2755-2775. [CrossRef] [PubMed]

76. Brozzi, F.; Nardelli, T.R.; Lopes, M.; Millard, I.; Barthson, J.; Igoillo-Esteve, M.; Grieco, F.A.; Villate, O.; Oliveira, J.M.O.J.; Casimir, M.; et al. Cytokines induce endoplasmic reticulum stress in human, rat and mouse beta cells via different mechanisms. Diabetologia 2015, 58, 2307-2316. [CrossRef] [PubMed]

77. Brozzi, F.; Gerlo, S.; Grieco, F.A.; Nardelli, T.R.; Lievens, S.; Gysemans, C.; Marselli, L.; Marchetti, P.; Mathieu, C.; Tavernier, J.; et al. A Combined "Omics" Approach Identifies N-Myc Interactor as a Novel Cytokine-induced Regulator of IRE1 $\alpha$ Protein and c-Jun N-terminal Kinase in Pancreatic Beta Cells. J. Biol. Chem. 2014, 289, 20677-20693. [CrossRef] [PubMed]

78. Choi, S.-E.; Lee, Y.-J.; Jang, H.-J.; Lee, K.-W.; Kim, Y.-S.; Jun, H.-S.; Kang, S.S.; Chun, J.; Kang, Y. A chemical chaperone 4-PBA ameliorates palmitate-induced inhibition of glucose-stimulated insulin secretion (GSIS). Arch. Biochem. Biophys. 2008, 475, 109-114. [CrossRef] [PubMed]

79. Liu, H.; Yin, J.-J.; Cao, M.-M.; Liu, G.-D.; Su, Y.; Li, Y.-B. Endoplasmic reticulum stress induced by lipopolysaccharide is involved in the association between inflammation and autophagy in INS-1 cells. Mol. Med. Rep. 2017, 16, 5787-5792. [CrossRef] [PubMed] 